『プリンキピア』（1687）の世界は，この時代をもっと もよく象徴しているようだ44). それは自由貿易を説くア ダム・スミスの『国富論』(1775)にはじまる次ぎの時 代の科学的成果, ダーウィンの『種の起源』(1859) と比 較して見るとき，明らかになる。ニュートンが神に演じ させた役割りは，物理学思想発展史の上においてる，ま た社会史的に見てる，彼の時代的限界を明嘹に示すもの であった。

44）「ニュートンは興隆しつつおるブルジョアジーの典型的な代表者て あった。そして彼はその哲学のうちに自己の階級の特質を具象化して
いる. (Hessen, B.: The social and economic Roots of Newton's Principia. Science at the Cross-Roads, 1931. p. 33) このように書いたヘッセンは, ニュートンから花き友人アシュトンに あてた乎紙 (1669) をるとにして，技術に対するニュートンの傤烈な 関心を証明し,『プリンキピア』成立の背後には当僻の社会の技術的要 求があったことを明らかにした。これに対してクラークは, ニュート ンの科学的活動期に和计る技術的関心を示寸资料はこの手紙だけであ り，乙たがってそれが正当に使用された場合，かえってヘッセンにと

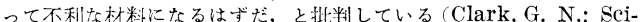
ence and social Welfare in the Age of Newton, 2. ed. 1919, p. 67.) 最近の著述のうちこの種の閔题に触れているのは Dijksterhuis, E. J.: Die Mechanisierung des Weltbildes, 1956, S. 269 ff.; 'Espinasse, M.: Robert Hooke, 1956, ch. 1 Hooke and Newtonian Science in England である.な拉, Вавилов, С.И.: Исаак Ньютон (Москва: Академия Наук СССР, 1945); Deutsch. Ausg., Phönix Iücherei, Wien, 1948 はニュートン の原子論を重樂なテーマとしていると思われるが, 参照できなかった。

\title{
諸外国之統計研究 III
}

\section{林 知 已 夫}

ロンドンから Manchester まで 4 時間かつる。英国で の交通費は高いし，距離聥減るしないのである，正に費 用は距離に正比例である1). 煙の多い Manchester の町 はロンドンより黑くよごれている. M. S. Bartlettには Pearson から紹介きれていた. Statistical Laboratory (Department of Mathematics)にいる.やはり一寸解 り難い場所にあった。多次元解析や stochastic process の忘用等で会う事を楽しみにしていた。太った大きい50 才位の英国紳上である。今まで会った人の中で一番英国 風できちんとしている、議論はすぐ始まった。自分は statistician である. 生物学啲現象に興味があり，これ を中心に考えていると言っていた，日本では stochastic process をあつかう人马多いが，大抵は数学関係の人で， 統計的な観点がないと言ったらっここでるそうだ数学者 的な取扱いが多く，統計的な⿻コ一゙全く弉くてこまると 話していた。食堂で彼は, 統計数理研究所は研究者が多く, 政究分野の調整が大変だろう，どうしてるやのた，と言う ので研究は自由方大切なので大絴や方針をきめたら各自 にまかせると言うと，それはたららしがないと言う顔をす る。あなたの所ではと言うと頭をか〉えてやはり自由で ある，その時々で—Danie1s の所と同様の意味— きめると言うのであった。なかなふ気の強そうな人であ る. 議論はまず多次元解析の話から始まった。 outside

1) アメリカでも闰蒜であった。 criterion としての分類の数が3つ以上のとき所謂判別囦 数 $y=\sum_{i=1}^{R} a_{i} x_{i}\left(a_{i}\right.$ はあるウェイト, $x_{i}$ は一次元の確率変数, $R$ は予淇因子の数， $y$ が 3 つ以上の層に分類されるもの とする) と畫いたとき，分類の效率をあらわす最大の相 関比やウエイトは $r A=\gamma_{1}{ }^{2} T A$; ここに $V$ は所調外分散 からつくられるマトリックス，Tは全体の分散からつく られるマトリックス，Aは縦心クトル（要素は $a_{1}, a_{2}, \cdots$ $\left.a_{r}\right), r^{2}$ は框関比; を解いて得られるのである.最大にす るため(この埸合極大に一致する)微分法を用いるのであ るから，その最大值のみが我々の日榑とするものとなる のであるが，こう畫いてくると他の根にも意昧がつけら れてくる。䐎最大を求めるために微分してゼロとおい た事にならめのである。このとき $(T)=(V)+(T-V)$ と 書けるのである。こ机は $\sigma^{2}=\sum_{i=1}^{R} \sigma_{w i}{ }^{2} p_{i}+\sum_{i=1}^{R}\left(\overline{\tilde{u}}_{i}-\Sigma^{2}\right) p_{i}=$ $\sigma_{w}{ }^{2}+\sigma_{b}{ }^{2}$ ，(第一項第二項は夫夫左辺の民机に該当する）; 一次元の場合の分散の分解, $p_{i}$ は $i$ 層のウェイト, $\sigma_{w i}$ は $i$ 層の内分散, $i$ は $i$ 鹰の平均值, $\overline{\widehat{a}}$ は全体の平均值; の自然な抆張である。そうすると判別函数を用いずに多 次元のま〉の全体の分離度の测度を $1-\frac{\sigma^{2}{ }^{2}}{\sigma^{2}}$ に類推して 一この類推が妥当なるのか不か諩諭を重ねたが扔互に positive な絹論を得られず, 多次元の分散を考えるとき に, generalized variance をつこうことの安信を指摘す るに止ま口た。な打分離度の別の测度として他のものを 用いた例を紹介して坮いた2).しかしこれも generalized variance をるととし，内分散に相当するものとして各 
層の generalized varianceを用い,一次元のときと同様 にして全体の内分散を求めたもので，次に定義するもの のも二嫳をのぞきうるが他との関速ではあまりうまいも のではない-1- $\frac{|T-V|}{|T|}$ と考え，これと判別函数 との関係をつけている。ここに|．｜の符号は行列式を あらわするのとする. 全体の分離はこの測度を用いると き，形式的にはととのうが左図のような場合，|T-V|

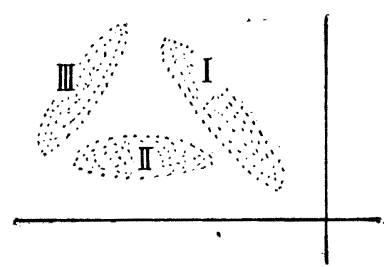

が|T|にくらべそう 小さくならないので, 测度はゼロに近くなる， そころが実際は実によ く分離されている.こ のような其合の悪い点 があるのである。この点を拝に指摘し，議論のさかん な所であった。一㤈これを認めるとすると $\frac{|T-V|}{|T|}=$ $\prod_{i=1}^{R}\left(1-r_{i}{ }^{2}\right)$ となる. $r_{1}{ }^{2}>r_{2}{ }^{2}>\cdots>r_{1} R^{2}$ とする. $r_{1}^{2}$ は前 の式の产べての特性根である。もし $\gamma^{2} a+1 \div 0$ であれば $\frac{|T-V|}{|T|} \fallingdotseq \prod_{i=1}^{\alpha}\left(1-\gamma i^{2}\right)$ となるので，Ｒ次元の分類はほ ぼ $\alpha$ 個の判別函数一通常は $\gamma_{1}^{2}$ に相当するものだけを 言う一を用い $\alpha$ 次元ての操作によって表現されること になるわけである， $\alpha=1$ 又け2であ机ばなかなか面白い 結果である。さらに朔に青いた $\mathrm{y}$ 力数值であり且二多次 元である壦合（このときは $a_{i}$ もべクトルとなる），を考 えてみると，xからyへの推定は $\left(y-\sum_{i=1}^{R} a_{i} x_{i}\right)$ からつく られる gereralized variance が最小になるようにべク トル $a_{i}, i=1,2, \cdots R$ ，をきめればよいのである.この結

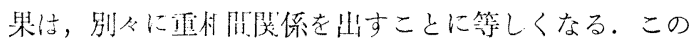

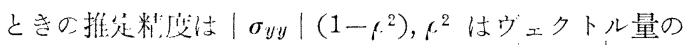
間の林関係数に利当守るもので $\kappa^{2}=1-\frac{\sigma_{x x} \sigma_{x y}}{\left|\sigma_{y x} \sigma_{y y}\right| \sigma_{x x} \mid}$ とな る.ここに $\sigma_{y y}, \sigma_{x y}, \sigma_{x x}$, は火 $(y, y)$ についての， $(x, y)$ にこいての, $(x, x)$ に二いての variance, covariance マトリックスをあらわす｜｜．|は如論行列式で ある。このとき $\left(1-\rho^{2}\right)=I_{i=1}^{R}\left(1-\rho i^{2}\right)$ となる. $\rho_{i}$ は $y$ と $x$ との canonical correlation である. canonical correlation を求める啰合も最大の $\rho i^{2}$ を求めるために 微分するのであるが，ここではその时得られる特性力程 式のすべての朴を求めることになっている. canonica1 correlationに関する手法任特別の埸合の特別な使用法 を除いては「推定」としては全く役に立たない，一般に 最大の canonica1 correlation のみを求めたとしても意

2) C. Hayashi, Multidimensicnal quantification, Annals of the Institute of Statistical Nathematics, Vol 5, 1954.
味がなく，すべての correlationを出してみてはじめて， 多次元相関係数と関係づけられて意味のでてくるもので ある, canonical correlation は推定用と言うよりむしろ, 多次元間の構造をみるためのものであると言う点で意図 の一致をみた。話はつきない. linear を関係(和)に何故 固執するかの問題に話が移った，彼は一応 linear な和 をもとにして，話をすすめ，これを多次元的につなぎあ わせて事を処理しょうとの考え方一これは何個るの判 別函数を用いて多次元の分離を追及することにあらわれ る, $\mathrm{y}$ の分類が 2 或は 3 以上のものであり一次元的のぬ のでないならば何個かの判別函数を用い多次元的に表現 する—ををっていた。 $x$ が数量として与えられて居り， これをそのまま用いる場合は分類の棦相によって， linear な関係が認められなけ机ば，また相互関暗性の工合 で和の形で表現しうる関係がみとめら机なければ有效で なくまた curvilinear にしても，この函数形がはっ きりしていなけ机ばなない，そこで，我々の数量化の system を用い, 数を与えなおし(定性的のものには数量 を与え) 和の形でゆくか，そうでない形でゆくか, いかな る次元を用いるか，をきめてかかる，そのような考えを 用いるべきことを強調し，論じ合った，Bartlettは所謂 㭥定に執著しすぎるため，それ以外になかなか頭がまわ らないが，明快に衝くべき所はしかとついてくる。なか なか面白い. Mahalanobis の距離にしても二つの間の 距離でこれを単純に拡張することは意味がないし（二つ ずつの距離の単純な算術平均はと，恥かしそうに彼は言 ったがすぐ取消したのがよい) Rao の考えは面白い所 もあるが，その多くは全く形式的で役には立たない，や はりなにか根本がぬけているなども話題に上った。 3 以 上のいくつかの分類をなるべく少い次元で行うことの困 難さ, 分離と言うことの测度のつくり方, その効率の妥 当な表現，が話の中心であった。お互にうまい理論を考 えようと言うことになった。ここで E. J. Williams (Division of Mathematical Statistics, C S. I. R. O. Melbcurre) と吾う人がなかなかよし研栄をしているこ とをきいた。很の机上には Bicmetrika 1955, No 3, No 4 にあるWilliams の論文か關かれてあった。

次に prccess の問題にうつった. 再び stationery の 問題の話になった。経溈では全く用いようとの意思がな かった．単純な絽織のものでは，用いられると言うが， いかなる意味で用いて有効であるか，を訊ねてみたとこ ろ，単純なる予測としてでのようである，複雑なるのは どうするかと言うので step by step にやる短期子想一 
一このために如何なるもの把えこれをいかに表現し， いかに調査をするか，その多次元的のるのを表現し，綜 合する手法が問題となる3)——方法を論じた，彼は常 に傾斜があったらどうするかと言うので，傾斜をいかに して推定するか, 少しのデータで可能か, stationeryの 考えでできるか，と述べこに empirical の大切な点 を強く要請した。彼は stationery process を考えると き，ガウス分布を用いることにあまり重きを扔かず，独 立性のみを用いて進める，しかしかなり多くのサムプル を必要とすると言う手法でゆくので，これは我及にとっ て同感なのであるが，変化する条件の下では多くのサム プルを用いることが出来ず困却を来すことになる．常に 変化する条件の下では短期予測の考えによらざるを得な いであろう。簡単な構造のみで押そうとする所が無理な のだ, 因子の behaviour とか past experience とか expectation とか（比喻的意味を含む）も考えに入れて くることが大切になるのである. Bartlett は敢て stationery に固執せず epidemic の問題をとらえて理論を 発展させている．戦に数学的な形式的な面で発展を生み だそうとする—これでは有效な統計理論がつくられる ことは稀であろう一のではなく，自己の得意とする生 物觉の领域に扔いて，実際問題解明を志して理論をつく ってゆこうとしているのである4). 麻惨の甫町村別の発 生状沉をもとにして論をすすめている。そこでは人口が 大切な要素となっている5). 上の論文に限らず Bartlett の論文には必ず応用例（そのうちには理論の基になった 現像を書いたものもある)がついて居り，データをいじ り自ら計算機をまわして答えを出しているのである。デ 一夕を実際に自ら取扱わずして，その特微を見ることは できず，解析の勘所をつくことは不可能である。データ の機構を古っかり知って始めて有効な分析法を試行錯䛊 によって一一何度も計算しては考えなおし……作り あげて心くことができる当のである。かねが权私の主張 する所で全く嬉しい限りであった。これにくらべ本の 現状は特別の所をのぞいては寒心に堪えないのである. Bartlettは私の見て歩いたうちの最も優れた人で，学ぶ へき点が多いと思う。考え方は椖晰だし，文献的ではな し, 深い洞察も女る，実際現象に対市る解明を考え，諭 の進め才湶が太く強引の所もよい，な括この上に自信

3）現象解析に括ける統㣔的方法 II. 科学基礎論研究, 第三号.

4)この点 J. Neyman む同樣である. 集団の大きさ推定一とくに mobile population に扔いて—の問题飞执いて関連性むるポフン ン分有をバクテリアをのぞくの對微鏡の中からつくり出している.

5) Perkeley Symposium 1956 の中の第四卷に発表される.
が恐るしく宿いのである。 Manchester の大学す教育 学部に Oliver と言う人と Warburtonと育う人が居り, 我々の数量化に興味老狩っているが Bartlett の所て思 わ辰時間を費し会う事を得なかったＭ汭chesterの 経济研究所でケインズ・モデルを水を用いて解く一種つ analogue computor をつくって動かしているのを欢た が，Johnstone は全く央際とは合わない一国民所得が 1.5 倍にも出たと言う一と嘲るように莘っていた。 L. R. Klein の方式はどうかと言うので，全く同様に面白 くないと思う(linearな阙係；但し特殊な要因法用いら れているが；でマク口的で，その方法では特別の㭙期を

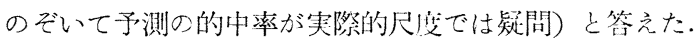
Manchester の町も郊外には立派な家がならんでいる。 英国のよき時代の遗産だと露う。友人は今日が Cambridge と Oxford とのボートレースた，白分は Cambridge 出身だと言うので代事をやめて夢中にテレビに見 入り，声をあげて声援していた，Cambridge が沟引な 漕法で勝つ，おめでとうと言うと颜を赤くして媴んだ。 大した人気である。郊外の商店街には木枠の中に壁をぬ りこんだ古めかしい建物もある.木組みでいろいるの模 様を浮き出して見ていると古い世界へさそいまこれる。 シェイクスピアの生地, 美しいアボン河にのぞむ Stratford on Avon6) へ行ったときる，このようないかに も西洋の昔と蓄った家々がならんでいた. Manchester の広大な工場街入入る手前に白慢の運河がある. Liverpool からつづくもので...Jj屯の船が自由に通れる。 ス ェーデン船がー一寸旗をひら女か世て通っていた。陸上交

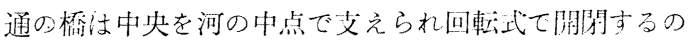
である。これだけなら何でもないが大運河の上に小さな 小運河の橋がかかっている。これもくるっと回転军る. 大運河に船が通ると立体交文する小運河の橋は回転して 「止れ」になる，橋が回転して小理河の水路へびったり つくと水門があき小運河の舟行がはじまるのである。な かなか醋白い見物である。

Edinburgh は古い北である. 何と言ってもごつごつ した岩山の上に屹立する Edinburghの城が目につく.城 の上にあるギザギザは大砲き鉄砲をのぞかせるためにあ るらしい，我々にとって洁何となくせまるような蒙を誘 うものがある. Holyroodhouse もスコットランド的な 沃野を背にした城である。この一体の公園は緑の起伏す

\footnotetext{
6) ここにシェイクスピアの㓺場があり Old Vic などがここでやる. 異った空間のすのを同時に無幦係に舞台でみせる演出は面白い，倾白 の意㕲がはっきりする，演仕心は近代的な感覚があった。しかし変な 所もかなり岕る。
} 


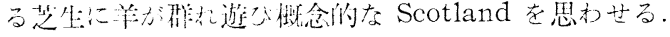
牧場の概念刀すきな人は，Scotland に限る。ここで自 慢侍人 Sir Walter Scott である。その生蒙, 住居など すべての Edinburgh 人の譇りと言う。この町では菖の 壁(Wall)が火切で烄くつついたものもあるが帆に新 しい建物の閐に2〜3尺ほど隼がのこっている場合もある。 これが们々時代つ们々としるされて大切にされる．黑 グラニットの建物が多いししっとりと落着いた町だ。町

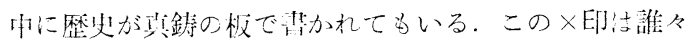

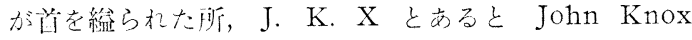
が死乞所だと説叫される。この家には何作から何㤰まで Scott か心た，行劣や家の礎不の跡の印（そのままに印 がついている) ……年に多いのである。しかしこれに

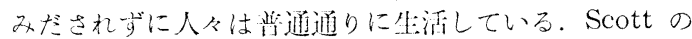
家にも以かりのない solicitor が住んでいる。ここで voluntary guide が世活してくれた，大恋竌切でよいが お国自慢をしたとき管如と忽に父咏が悪くなるのにはび っくりした。エディンバラの人が最蚄りとしていると 方う地点であまり興味を亦さないでいると，気嫌が大変 わるくなった。そこでとりな市うな事を言ったら，真 実か，真寒かと何度めきいてくる，次第にほめて行くと すっかり気憡がよくなり能弁になるのにはおどろいた。 其の Edinburgh 祭には町中の劇場のいたるところにす くれた音楽や做劇などが䦌かれるそうである。ここの

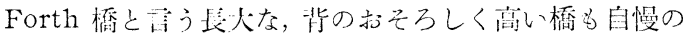
一つである。ここの渄は深く桥の下は潜水艦がくぐれる と害う．基地が彼力にあるのたそうである. City obser-

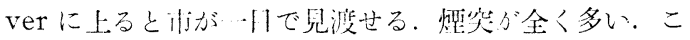
の丘の上に，大きな建物の出来かけがある。これは昔の 時代，出露過多のため工等が中止になったままで，その ままのこっているものたと护う。面白い残りるのであ る. Scotland の菜はわかりにくい，始め英語でやっ てくれと司うとよしきたとくる．最初のうちは英語でわ かるがすぐスコットランド叱りになりためめなって了う. Edinburgh の大学よりも，由繅ある高等学校の方がず っと立派である. 数学, 統計教室はここでもきたない小 オフイス風の建物の中にある。

二陷建ての市電が走っている。勿論バスも二階である。 …階は insideで二階は outside である。outside へゅ けと苦われると始めは戸迷ってしまう．郊外Holyroodhouseのそばの昔ながらのタータンチェックを売る店の

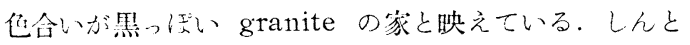

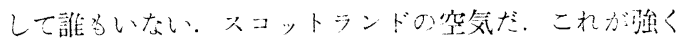

四偣に残っている。

Edinburgh を過ざてAberdeen の大兴二ゆく。世界 で6番目に古いとか言う大学である。Aberdeen は相当 北部で東方の䬺に面している，有名な漁港で焦市場があ る.ここの大学には森林調査や実験の計画法で知れてい る Finney がいる。また魚の populationについて統計 的な研究をしている Bureau当あると言う. Aberdeen の潐悲は活い．鷗が多く飛ざ交う。ここへ魚がつくと競 りが始まる。潮つ干満がはげしいしい，港のつくりが そうなっている．您の箱の上に長靴で乗って競りをやる. 正に internationa1 な風景である。呼び芦は日本と同 杼，いずれの国で当はっきりしない，きまると自分の家 号のついたレッテルを㧍いて，馬車や自動車ではこび去 る。実にいそがしく，交通整理も大変で市。魚河岸に いそぐ女の魚屋三人る長靴であったが妙命つ一人には耳 飾りが下っていた。旧 Aberdeen はこれと打ってかわ ったす代らしく美しい所である。そこへ回るのに旅岸通 りを通ってゆく、引㪰茶のひろい砂浜に波が小さくさざ めいている，淤岸では 4,5人で大きな網をはっている. 非常にはげしい潮の満干を利用して魚をとるのだそうで ある、英国に海岸は多いが，美しい砂浜で，たのしく泳 げるところは献部のトーケイ，ボーンマス等実に教いと 言う. Doverなども全く石ころの荒海である、アメリ カとても同様で, 日本出有難い限りである. 游岸の歓楽 場を奴けて陸地へ折机ると急に世界が変る。扔るちゃの 世界，打伽の世界に迷し込乞だよな錨临を扔こしてし まう。広口の漏斗を作せた椂な側面をしている北の低小 家々その上には小ぢんまりと煙突が立つ，しっとりした graniteで出来ている. 落ち着高のある任帘りの不多舆 造作に法めこ去礼ている。類似の調和で亦乃う。このよ うな家々がしずかに清潔に並んでいる。たしかに妖精引゙ 住んでるよい，外机にはしずかな川と一つのアーチ型の granite の橋，アーチの先が少し尖っているのも楽しい， 朝日に映ると 'Scotland' が望見される。この附近の美 しさは格別である。 Finney氏’よ旧Aberdeenの外れに ある Marishal College にいる. 入ってみると大きなが ラン堂のような所で多くの女の計算手が $\chi^{2}$ だの $\rho_{1} \cdot 23$ だのを計算している。や伭りマーチャントをつかってい るて，昔つ我々の研究室こっくりの感じがした．Finney

\footnotetext{
7) スェーデンではフォシット、イギリスではマーチャント、アメリカ ではモンローが多いのである。

8）スイ六製の日本にきているのと同じで、33 ポンドと尝ろ。一寸やす い上らでちる
} 
は大変元気のよい人で机の上には小型計算機8)が执いて

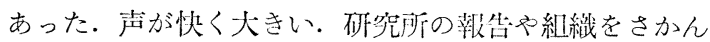
にほめる、外国人の抽てにはすっかり経験济みでうっ かりするととんだ笑い物になる。さっそく森林調全の話 にうつる、我々の経験を話し，その後の研究をたずねた が，Finneyはその後は森林調查の問題はあつかってい ないむかしインドの资料があったのでやってみただけ であるそうである．彼のは森林調查に打いては地点の抽 出によく等間隔抽出が用いられるのでその閣题について の精度を諭じたものである。少泛的には何か物足りぬる のがあるので，きいてみたとこる山へは入ったことがな いと言う。しかし De Lury に対する批判9)や Matèrn に対する批判（地点間の相闒はよ゙うして知られるか，何 か解らぬものをるちこむのはよくない）は正觜である。 森林調查で各地点のとり才で○は理論的にはよいが，策 際的でなくロがよい，等と話すと興根をもち出す。あま り面白いものではない，彼の興味は令 design of experimentである.そこでかねがねの疑問を呈したのであ る.モデルのlinear性や error 項のガゥス性, 分散の同 一性はさて扔き，实験の条件のとり方（その分類の数） そのウェイトづけの問題，実際の状沉をよく表现するよ うな計画の方法（飛行状態をみるために風洞实験でつく られる実験条件のようなもの）や検定の意単変，数の変 換について話したので亦った10)，条件のとり方を落える ときにも目的をはっきりさせ条件のサムプリング（この 確率や標栈の去えおが大切）を将えに大れるべきであ る，こ机にはまた variance の controlの落えも入れね

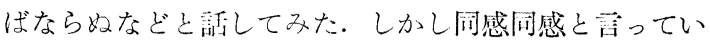
たが解沃にたいしてはさっぱり要领を得なかった，彼白 身は条件は 3 分類 (上中下) がよいと芯っていたが根拠 は曖昧である。所詯奏験計画法は生物现象に用いてよく， 一般に工栄方面で住 optimum condition (Box) を求 めるのがよいだろうと苦っていた。いま順序を落えに大 れた designをとりあつかっていると荘う。これはそう 新しいことでなく我々も前に取扱ったものであるので，

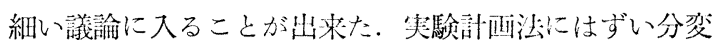
な本があってこまると司ったら，本颀走解している当の は眇い，同感同感と言う。しかしいず机にしても根本に

9) D. J. Finney, The estimation of errors in the systematic sampling of forests, Journal of the Indian Society of Agricultural Statistics, 1953, Vol V, No 1

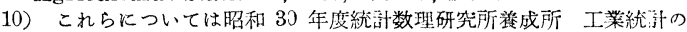

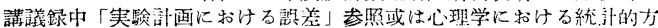

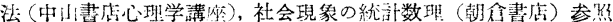

ついては彼はあまりよく将えていないようであった。た

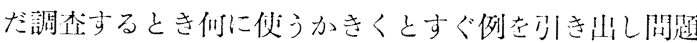

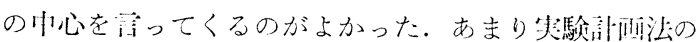
問題点ばかりをつつくので，少ムプリンク調住でも贽用 の函数があいまいであるが design できまいとついて きた，サムプリング洞查のううは玟价们なるのではなく，

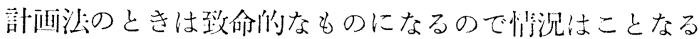
と説叮した。多次元の分敬分析の将えJなどる质に出た。

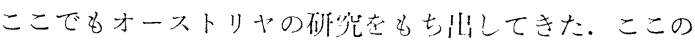
焦の population の破究も大したことかなく行く必恶は ないと氙ったのでやめることにした．Finney は「滺で

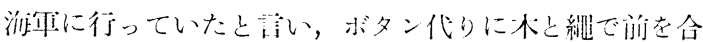

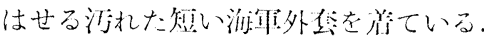

苏目はこれで終りである。イースターの优みを利用し て， Dover から Calais にわたってみた. Dover の白 い壁はたしかに㕕大で挑ではあるが緎絒なうしさに欠

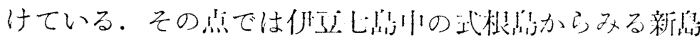
のはい壁は限りなく fine11)で奖化にとんで犯しい。ここ

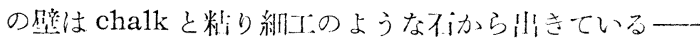

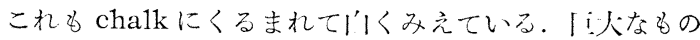
でこの壁の上の敞策はたのしいものである. Doverの

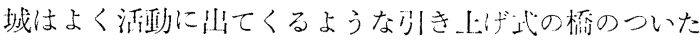
城で，川は䓗が少く全く棌い。これではロビンフッドの

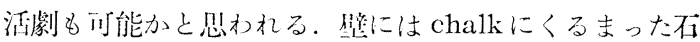
をたたきれって尖がししたるのがはめ达儿で志る。休为

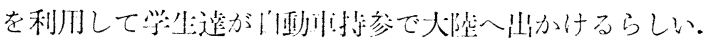

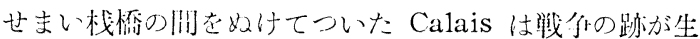

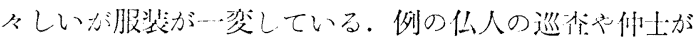

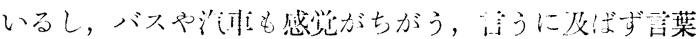
の感じもちがう，わずかの趾漓倠なに，赤げのついた

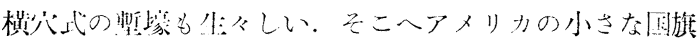

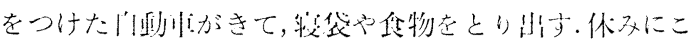
のコンクリート式の塹榢で，川本で、すおッンプをする

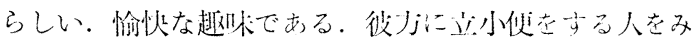
かける。外目ではないと䦌いていたがあてにはならない。

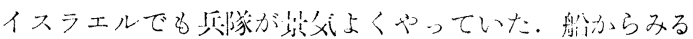

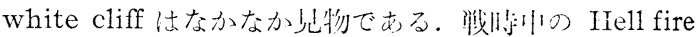

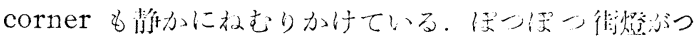

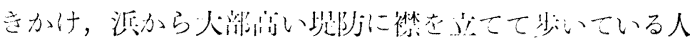

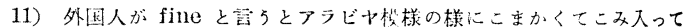
いるが一定の丝純な数学的法则で虫来ているものを指すのではない， 一兄 at random の核にみえて神終がさきのさき东ていきとどいて 溇り上げにもの在り5よ5である。 


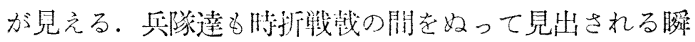
時の静かな自然に耳をかたむけたこともあるう。浜でョ ットやボートの開で甽の若备が大声でさわいでいる。夏

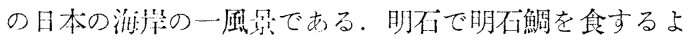
うに Dover で Dover sole を食する，北游道で松前 こんぶを食することになりはしまいかと一寸心配である。 英国人は拉となしい，ロビーでもそう大さわぎをせず， しきりに紅茶を飲んでいる，伀筆西人と全く感じがちが う. 英国では若い女やホテルのボーイなど thank you をサンキュッとつまって萑う。「・・言葉」であろう。 こ机が耳についている。ここでも旅の錯觉を意識する。

よく英国を見習光と閃く。しかしただ一つの事を見習 えと言っても無理である。全体の調和を考えなければな らない，パーソナリティの样な有機的なるののよい所だ けを習えと言ってもこれは抽象䠼である。よい所は裏を 覆えせ代瑟い所なのである。よいるわるいる表裹一体な のである。まねをするならげすべて真似するのでなけれ ばガタピシになって存機体は成立しない，聖書をホテル の各室に招き，親近感を以て主王の写真を真面目にかけ て㧈けること，音楽会や莎泀の時国歌を奏すること，国 旗をよく用いること，白国が圮界で一番よい国と思うこ と，外国に傾倒して间同内で侧問割れなどしないこと， すべて自园中心で考学ること，伯己の利害についてよく 考充，イデオロギーなどにあまりかまわ奴こと，何事に

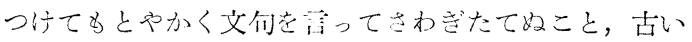
伝統をかくまって招くこと，忍附除く同じ事をこつこつ やり自信をもつこと，階級制度を不思議でなくちゃんと まるること（分に念ずる行動をとること），地下鉄の蜚示

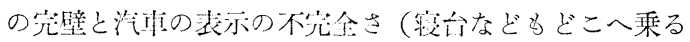

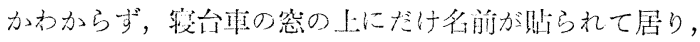

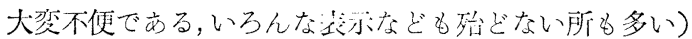
の対此……あげれ机きりがない，しかしそ机なりになに かバランスがと机ているので京ろう。沶そるしく違うと

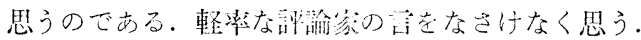

いかにもアメリカらしいPAAでニューヨークへ向う，

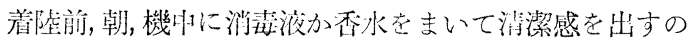

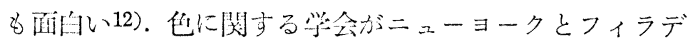
ルフィアに閒かれるので出掂するつもりであった。一つ は Inter Society of Color Council でるう一つは American Optical Society である. 色統統計一一色空 間のつくり方, 標準色紙の選びう, 色の感営的制定 (色度,

12）便所でも英国では手洗いがなかった。これには閉口する。しかしア

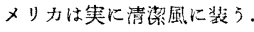

コントラスト，調和等）にからむ問題，色彩現象の社会 調查等——領域に扔いて関係の深いものが㐫る。とく にJuđd と言う人がュニークな研究妾している. Inter Sociely はニューヨークの Statler ホテルで開かれた。 かの有名な Munse11 の色紙の系統の人と話し合ってみ たが，これは技術的な面にのみ興味が集中していた。こ こで配引れた資料の中に色についてのクイズのパンフレ ットがある.きれいな色づりで,かなりむづかしい質問が ある.クイズ流行であろうか. 中に How many colors is it possible for a normal person to perceive? とあり答えに 10,$000 ; 10,000,000 ;$ 、。ありこのうち から一つ選ばせようとしているがアレフ零が面白い。 Optical Society のJはフィラデルフィアであった，古 い町で道路工事, 小さい市電, 道のわるさは日本の大都 市を思わせる．昼間でも暗かったせいかネオンがきらび やかに輝いていた，非常に彩度の高い色合いに感じられ た。ここで macro 的の色差と micro 的色の差とは別の るのであると気づき出したらしくその発表があったのが 面白かった．色の空間は一応三次元とは言いながら等色 差で色を表現するためには三次の次元をぐにゃぐにゃに する必要があるので単純な座標式表現をとらないのがよ いようにも考えられる，学会の司会はューモアたっぷり で，て談をさかんに用いる。しかし発琵者の紹介るやり， また一人一人の護演を要約して話して，質問をとるなど 大変棓切である。シン尔ジウムで惊とくにこれが有効と なる、緊張するとみなうまくユーモアを入れた表現をと る、最初侍咄弁でごつごつし次第に油がのって能弁にな っていく話しぶりをするものもあって，楽しいものであ った.

ニューヨークは実に面白い所である, 感觉をチョイチ ョイと刺载するところ龙楽しい，覀口を言う人があるが 私俚无うは思わない、ビっくりみてゅくと実にコクがあ る.さすがに古さの興趣をたたえ，その中にいぶしのか つった珍奇さるあり，アメリカ随一であろう，それなり にョーロッパ臭が根抵伅あると子言える。交通规則子実 にやかましくて自動車を駐車するところも，禁止場所が 曜日・時間によってことなり，うっかりすると罰金である。 わざわざこまらせるのかと思うとそうでないらしく，駐 車していない所をみはからって摗除車が回転删毛の上う なもので掃除をして行く、E大になり，自動的になると それなりに別の面で不自由ができてくる。ニニーヨーク で睡限道具を売っているのには警いた，for good sleep とあり黑い眼带と耳につめる栓を莣っている. shelter $\rightarrow$ 
とよく書いてあるので何かと思うとこれは大きなビルの 地下であって，原爆用の防空壕であると言う。これで演 習をするのだそうである.すっかり要心墚い.プロード ウェイ, Time Square のネオンはすばらしいが13)，あま りすべてが巨大なのですぐなれてしまい相対的に大きさ を感じない，大きさを実測して東京にもってきてみると 実に大きなるのになる、特に高い建物を除いてみると， 最頻值は 15 階建てである.ここでお好み焼 (Plazza) を腕前をみせながら焼いている所もある。このとりすま したものと䳸民的なものが入りまじっているのはガタガ タしてよい. 白く髪をそめた若い女子多い.

アメリカの一見アメリカらしから好所のあること, こ れがアメリカかもしれない、ニューヨークで，扔そろし く污ないバスや地下鉄, 地下鉄の駅には1セント入れると チューインガムの出る機械がみわたす限り並んでいるが， 半分位は機械がこわれていて金を入れても出てこない, 税関は扔そろしく気長で人数も少く，のろのろと仕事を する，ホテルの朝食は打そく，ヂュース，パン，コーヒ 一，これで 1 時間半もかかってしまう，バスのおそい事 天下一品で動いては止り動いては止り（停車場の間隔が 実に短い）運転手がすべて金のやりとりもするので，そ れがすまないと出発しない，地下鉄や汽車の表示が不完 全である，メトロポリタンオペラハウスの椅子には遠眼 鏡がそなえつけてあり，25セント大れるととび出してく るがあちこち故障だらけである，下町の Greenwich で は馬車で野菜を売りにあるいたり，そこの Washington Square では大道将棋をやっている, Central Park で は茫生にリスがむ机あそび，乗馬道では茶のシルクハッ トの乗馬姿も見える, サンフランシスコでは坂道をケー ブルカーがのろのろ往来し，運転手や車掌が乗客と世間 話をしながらのんびりと動かしている。しかし Centra1 Park に池があるが金網張りで，これは飲み水にするか らよごすなと現害的なことを言う。

博物館へゆくと英と米とでは甚だしく様相が異る。ア メリカのは学校のようなものであり，教えるようにでき ていて，贋物でもが゙り，現場に似せこしらえて，よく説 明してある．例えばェヂプトでの一寸した本物つ一端が みつかると，かつてこうであったろうと言う大きな構造

13）飛行耭会社の TWA やペプシュラ, Kleenex と悹5化粧紙の厷告 などがとくに目につき，酐画館の入口から歩道にかけた雨よけの数か しいライトもきれいである. Camel の「垔を吹く人」の広告もあま りにす有名である。一体にきわめてあかるく，桃色，青や緑が少く， とにかく白色光系で粨くのが多いのは品がよい，日本のは暗い光のく せにあまりにす裳色が多すぎる感じがする
物をつくりあげ——過去の研究でたしかめられているこ とであろう一本物をこの一部にはめこむのである。現 場の感じを再現しようと言うのであろう．水中の有㥞な ぞ合成樹脂でうまくつくってある．イギリスのは日本同 様めずらしいもの，堀り出したものをならへ，説明污し てある.アメリカの博物館は学生だらけである. 大むか しの動物の巨大な骨はたしかに本物のようである，奇妙 な土地のことも図書館でしらべ，言語を学び，博物館へ きてみれば正に some ideaをもつことであろう。一通 りはこれでよさそうである.

アメリカは戦前と戦後で大変変った。戦前は小供で, チャッチャッと言う踊りそのものであったが，一般に戦 後は随分大人になり落ちついてきて，わでなども解して 深味がついてきたようになった，と闭時代を見た新聞記 者が話してくれた。たた町の建物の様子など 2 年半前と 戦前では殆ど変ってないのには警いたそうである．戦前 の不景気一戦争一朝鮮戦争と戦争後は軍力に力をつかい 人々の生活に手がまわらなかったが 2 作半前位からそち らに目が向き出した感じたそうである．古いビルが打ち こわされ新しいものが目ざましく建ち出したらしい，古 い低いビルと巨大な建物が混在している。また戦前もい た Time Square の新聞売子は命日も同じ恰好, 同じ売 声で，昔と同じょうに自分のところへも新閒をるってき ていると言っていた．郊外へ出るとハドンン河に見物が ある．戦時中のリバティ船がつかえないので，河に浮ミ これをつなぎ合わせて晸物倉成にしていると言う，実に みわたす限りである．思い切った事をしているらのであ る.ニューヨーク郊外は信州刀感に゙に近い，別荘では上 メントでつくった大きな咠をペンキでぬったダフニスと クロエるいるようである.

Princeton 大学では Tukey と Stephan に会った. しずかな町である, Tukey ですと言って出てきたのは 思いもかけず柔道家のような巨漢で, 黑いポロシャツを 著込んでいる. Deming もきていた。 Deming は佐 藤先生や水野さん，私と浅草の観音さまのうらをあるい た事を言いだした、日本ではいろいろ引っ張りまわされ てすっかり疲れて了うと言っていた. Tukey の所人 Varianceの計算をたのみにきているらしい. Tukeyは モンローを前に計算をしていた。一寸面白い風景である. Moste1ler, Tukey, Stephan, Deming と何か連繋が市 るらしい. 此頃 Tukey は全く実際的なことに興味があ るようである、部屋は散かしっぱなしで，議論するとき notationを好かしたり，Daleniusと间様オッチョコチ 
ョイの感じがする。しかし鋭く pointを質問し，実例は とくる。彼はすぐ黒板を利用する，英国ではなかった事 である.まず変数の変換や数量化の話をする，抽象論を やっていたとき I don't agree, I don't disagree など と言っていたが，実例で論じているうちに“妥当な意 味’を了解し, discrimination power を最大にする考 えの下に変換したり，量化したりする話にもちこむに至 って一一素朴な測定数量は実数としていままでの統計的 方法であつかっても妥当なことが出ないかもしれない事， それを考えな招军事が第一の統計の仕事であろうなど一 一互に話が進みあった。 scaling の事は気がついていな いようであった，黒板に足をあげ，椅子にひっくりかえ って話をする。なかなか面白い話をする。 discrimination の話, 多次元の分散分析の話, multiple comparison の話14)，彼は多次元の分散をあらわするのとして 所謂 generalized variance の考えに同調せず，別の測 度を礼らっているようである. 確かに我々にとって generalized variance は一つの固定観念となっているよう に思える. multiple comparison ではk-sample の問 題で range をとってやっているのであるが，別に深い わけがあるのではなく，これがやられていないからやっ たと言う．何を測度としてとって子異諭はないようで あった. vector 量の k-sample の問題も同じく多次元 の range を定義（各次元に扔いて最大をもとめ，つぎ に多次元を比較しての最大をとる)することによって同 様に考えられるが訃算は面倒のように思える15). 次に検 定の妥当性に扔いて，例えば $m \times n$ 分割表に扔ける独 立の定燨 も $p_{i j}=p_{i} . p_{. j}+\varepsilon_{i j}$ と $\varepsilon_{i j}$ を付して行う（この $s_{i j}$ の大きさは妥当性の光の下に极いて決定される）こ とが考えられこの問題について論じているうちに, 差と して $p_{i \cdot p \cdot j}-p_{i j}$ がよいか, $\frac{p_{i j}}{p_{i} \cdot p_{\cdot j},}$ がよいかと言いたしした が16)これなども $\varepsilon_{i j}$ の問題である. Stephan とはサムプ リングの問題では別に話はなく検定論の立場について話 したが，彼も弁別域は theoretical でなく actua1 な立。 場からきめると実際家らしい事を言い採択しなければ一 一逆の立場一何もならないことも考えている。ヴィタ ミン不足で視野に星があると萿うので，黒い眼鏡をかけ

14) Discussion, Journal of Clinical Psychology, VolVI, 1950 ; Causation, regression, and path analysis, Statistics and Mathematics in Biology, 1954, Iowa State College Press; Dyadic anova, an analysis of variance for vectors, Human Biology, 1949 ;

15）これは未だ成披われていない。

16) $\frac{p i . p . j-p i j}{p i \cdot j \cdot j} p i . p . j=p i . p . j-p i j$
ている，ユーモアたっぷりな紳士である. 北の施に Kingstone, Queenston がある。ここは Princeton と言 う. Tukey は 1930 年型位の埃だらけのボロ自動車を 楽しそうに運転している. 変った趣味である. Princeton の有名な研究所は大学より 5 哩代かり離れた所にあ る. 尖塔のみが川の向うの森ごしに見える.

ニューヨークのI． B. M. では 704, 705 をみた。 704 は科学的計算に適したもので速度はきわめて速い. 650 型の進んだものである. 705 は commercial 用と言う. 記憶はテープ, core 併用で，ドラム記憶も用いられる. 印刷子実にはやい. tube の 1 操作は一秒間に $10+6$ と 言うのである. I. B. M. の説明をする技師はジャズが聞 えだすと目を輝かし前かがみになり局や腰を振りながら やる.これはいまだ米国でも数社しかもっていないと言 うが，日本の実業家が見にきたと言う。買い込みはしま いかと一寸心配になる．莫大な費用である．事務機構の 整備（大して人手の削減にもならない）につかう予算 （外貨）があれば本当にオリジナルなるのを生み出す技 術そのものの進歩につぎこむのがよさそうである。この ような道具はすべてアメリ力的規模の上に立っている道 具なのである.日本ではもっと高性能適切な道具を自ら つくってよいと思われる．M. I．T．にある計算機はメ モリーが 3 厅と言う大型のものであるが速度は扔てくも う旧式である.いま Lincoln の会社と提携して極柲つ 研究を進めていると言う．M. I . Tのでるバッチを胸に つけての見学であった。

Boston はニューヨークから汽車で 4 時間位の所にあ る.イギリスで汽車や電車の中で全くよく聞かさかれた sorry,だの I am sorry だの々言う言葉はアメリカで は殆ど聞かれない、 von Mises がかっていた Harvard 大学人行くつもりである. von Mises は今は故人であ る17).ここでは Emerson Ha11にいる Mosteller に会 うのがよい，その前に日本に来ていて，読み書き能力で 努力した Pelze1 に会った、今はHarvard の東洋研究 の associate professor をしているのである. 前から親 しくしていたので打ち明けた話を聞くのに都合がよい. イギリスでも教授が多忙であるがここではときくと全く

17) Richard von Mises はユダヤ人である. 確率論の大家であるばか りでなく航空力学や応用数学の尃門家でもある. 第一次戦争中は操継 者でもあり，航空機の設計者であったとも言う．佊はまた詩人リルケ の権威でもある.彼の一般的思想は Positivism, a study in human understanding, Harvard Unjversity Press, 1951 にのベられて るる.

18）これが大変なことでいろいろの foundation に研究題目を出し，

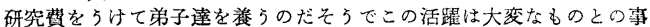
である. 
そうであると言う。研究費稼ぎ18), 事務, 研究会, 委員会 で全くいそがしく associate professor 位だと会うのが 極妨て難しいと言う。一ヶ月前から申し込ま枚代無理な 位であるそうである。一寸名放出るとこれで若いうちで ないと兔強できないらしい.ことにM. I.Tの教授は学 校以外の仕事が多く講義は休み勝ちで salesman professor の名があると言う. 有名な教授で年俸 2 オドル， 政府や会社の䧹問で 2 万ドル（このためワシントンへ行 ったり，他所へ行ったりする）計 4 万ドル位入るそうで ある。このように飛であるいているので実際仕事をして いるのは助教授以下らしい.しかし大学では他所からの 収入や原稿料は全部学校一入れ，本人は俸給だけのとこ ろも多いそうである. Harvard の制度は 30 才前の時 （よほぼの有名な人を除く） 1 年:知:契約し 3 年つづく と次に 5 年の契約をやる。これがすむと終身の職となる

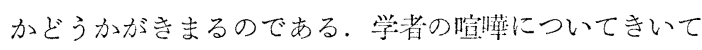
みると単に学問上の事丈ではなく，敵対するもの同志は 万般について争うもので意地墨をしたり, 徒党的になっ たりして，会議の時なども親分がとなえると一同右左そ れにならうのだそうである。全くはげしいと言う。ハー バート社会学の二人の学者の間の煊㗆はずててに亘って 激烈であったと言う.イスラェルで聞いてもそうであっ た、イギリスでもPearson と Fisherでもそれに近い ようである．外国の諭争は学問上の事だけとは全く碑で あると言っていた.アメリカの現象をみていると,何でも ないるのに新しい名をつけているように思えるがこの理 由はと訊悋てみると，新しい䩸に古い酒を入れてある ようなもので，新しい名は研究費取りのためであると答 えたここの研究費とりは劇烈らしい.そこでうまい婊現さ とる。何か研究费を foundation からとるに注新味かな いとまずいので一寸名や北式をつけかえて言いなおしを やるのたそうである19)。こうしないとなかなかうまくな く世智辛い, social science ではまずいので behevioral science と㝘う。そう方ると Ford Foundation 加ら金 が出る、 automationにしろ, operations researchに しろ，その他沢山の新しそうな名にしろどうるこの類い らしい.ここで閥くと,新しいGulbenkian Foundation が 1957 年から活動するそうで市る。石油での大金持で ポルトガルに住んでいた人の金がるとで，ここかイギリ

19)このことを Guttman にたしなめたとこらやはりそうたと寻って 笑い出した。

20）大金持が死奴と税をのがれるためFoundation をつくり缝用する のである・アメリカも大全持がいなくなったので後はだめだろうと の事であった。
スかに本據を置くと言っていた20)。やはり behaviorał science の領域の研究に出費するらしい.アメリカは参 加しないので日本には有利であろう、学者の外国旅行観 察の話も出たが,「学者の钼察は一辺倒であるから全く信 用できないし，評論家の評論も日が曲っているのが多い， ちゃんとした新聞記者のが一番よい」この現象は日本で もアメリカでも同样であると萻う.中りの記事ではニュ ーヨータ・タイムズの記者のが一番優机ていたそうで㐫 る（学者のは何でも彼でも悪く言うそうである，日本の， とは全く逆さまである) 名をきいた丈けで内容がかかっ てしまうるのが多いと言う。 international な現象子興 味深いるのがある。

Emerson Ha11はHarvard21)の占い所にある.ここの Laboratory of Socia1 Relations へゆく.まず Bales: に会う. sma11 group の社会心㰣的研究で面白い観察 法を洘えている人である. 所謂 group dynamics の観 察室をうまくつくり上げている. group dynamics を

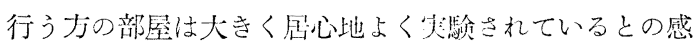
じが少い、観察室も功ったりと記録でき，閌の magic. mirror も大きく大変明るい. Bales の才法は small group が互に論議を交わしているの在記錄するに当り， 発言をこまかくきり，その区切られた内容を彼の作った

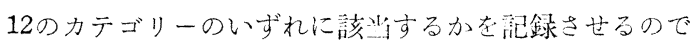
ある.このカテゴリーはdiscussion process をよく琵現 するように工夫されているのである22)。観察用紙は自動 的に一定の速度で動いている, 動く白紙の下に色がラス

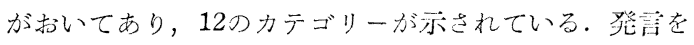
聞いて該当する所に誰が誰に甜したものであるか，それ はどんな内容かをカテゴリーにわけて揤すのである（こ のとき，いかくつのコードにまたがってもよい，その時 はいくつるのカテゴリーに阔㭙に范入する).こうなると 観察者同志の一致性（発晋の切り才やカテゴリー分けに ついて）が問題になるので十分の訓練を必要とする。こ のため大きなボードが壁にあり，12のカデ゙リーがしる されてある，またあとに5つの管球があり，各観察者 （5人）が該当カテゴリーのボタンを抑㐫とランプがそ こにつくようにしてある。発舒の processをみながら各 観察者は判断を行いボタンを抑し，各问一一致性をみる。 この外机工合を各人その場その埸で仪省し修正し訓練さ れる。よく訓練されたものを大れて就くと一致が速に行

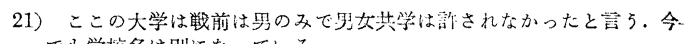
でも学校名は別になっている.

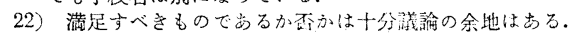


われる. 後から諭議したのでは process 中のことは忘 れて了うので効果は滰いが，これは仲々よい道其であっ た. 主として 2 人の場合が観察されていた。ここの sociometry の研究もなかなかつく所をついていて面白い るのがあった23)。ことに sociometryの validityについ ては我々とよく意見ぶにているのであった．R. Hyman は“読み易さ’の间題を Raoの multivariate classification をつかってやっていたが，心理学者のためか 意味がよく解っていない. Mosteller はstochastic model in learning をつづけている. 機械的で面白くない と者ったら次第によく古るからと言う。また判定者の reliability の间題老あつかっているが， reliability は 対象物を discrimination するときに間題になるから， この観点で将えると们っていたがその通りであると思う。 Tukey との共间研究らしい. 多次元的に考える paired

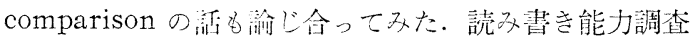
を昨件米国でやったらしいと言う。やはり政府の文皆や 税金の文書は難しい上うたと話していた。アメリカでは

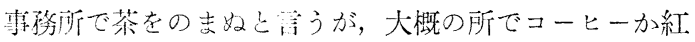
茶希りってくるのである. Moste11er は思ったより年寄 りであり，护慗的な䦌題に非常に興昧があり，且つそれ に手をつけているそうである。

Harvard の数授の club には何ヶ月鸟金を执わない 人の名はそこの立閉に张り出すことになっている。これ は大変恥になるらしい，背借金を返えさぬときの「門前 で御笑い下さ机度く……に似ているようである。

M. I. T. は Harvard のすぐ近くでやはり Charles 河 沿いである。ここの狱に三点支えのガラス張りの変った 劇場があり，その前には小さい濠をめぐらした感じのす る城のようなつくりの超モダンな円型の教会がある. ど の宗教にでるつかえるようにと言うので中は壇と椅子と があり壇のうしろには細い棒が立ってここにピラピラし た黄色の小さい板汃 at random に貼りつけられてある. 勿論小じんまりしたパイプオルガンはある．各自自分の 宗教の道具をここへもってきて式をするのだそうである。 円型の会堂の屋根は平らでここにアブストラクト型の尖 塔が立って鐘が下っている．各宗教のもつ印（十字架と か特殊の印とか……) のアブストラクトで，各人見様に よってはそのようにと机るのであろう。すごい一般化で ある、アメリカらしい栲えであろう、軍事教練が向うで

23) G. Lindzey 編, Iandbook of Sccial Psychology, AddisonWesley Publishing Company, 1954 中 Lindzey and Borgatta による Scciometric measurement
行われているが，我くのよくやった小隊教練をやってい る. 全く妙な現象である. 近代兵器も精神的な訓練に重 点を扔くこの教練が必要なのであろうか. Harvard が 英国式一特に Charles River にそうボートハウスあ たり，贅沢な寄宿舎 (全寮制) のむたり，建物の感じ一 一なのにくらべて M. I.T.は明るくアメリカ式である. 囯書室も全く遊じの感じがする。派手な服装の学生がち らちらする．M. I.T.でも精神教育が必要と言うので 戦後社会科学の分野が教えられると言う。ここに mass media の content analysis24)をしているRool がい るので会う約束をしたが，急にワシントンに呼ばれたの で, Perlmutter と言う弟子に会う.いまここの中心問 題は国民性の研究で，質間紙法によってやろうとしてい る25)，インド，アメリカ（ハーバート，ボストンの大学 生）ドイツ(ベルリン大学の学生), フランスについて行 っていると尚う。しかし対象はみな学生であり，質間は 所謂 completion（文章完結法, projective testの一 種）によっている。こ礼によると解答の coding が困難 なのである、国民により frame of reference 方ことな り，考え方がちがうので非常にむづかしい，印米独の三 人の学生を用い50時間訓練して，その一致性をみたと宫 う。一つの解答に著目すると70\%位三人が一致すると言 う。全体を通してみるとあまり高いものではない. code は解答者の心理を coding するのではなく，解答せられ た factそのものを coding する flat coding であるそ うである.これにしても難しいであろう. my family is O. K. と言うのがあるとどう code してよいか解らない ので変な code をつくって入れることにしていると言う. 各質問を code したあとで綜合的にまとめるまとめ方は 難しくまた舆昧ある所であるが, 間題だと言うだけで要 領を得なかった。怙机にしても面白い研究である26). M. I.T.の中の宛先多数字符号 (code) だけであるの 面白心.

Boston はたしかに new England の名にふさわしい 所で,アメリカで当珍しいそうである. Bostonから New London, New Heaven, New York と帰ってくる. 近代的なラガーディアの飛行場には色とりどりの飛行 機が往き来する，東京駅で電車汽車の出入をみているよ

24）新聞記事の内容やその出方なぞを科学的沉分析して表現する技法. 25）この考方方は私々の行った「統計的にみた国民性の研究」（教育統 計一交部省調查局統尌課編一30号参照) と同粎である。

26）国铇性の一連の研究の中印度についてはKali Prasad; Patterns of power-communication, an Indian Study, Center for International Studies M. I. T. No. 11-55/21, June, 171955 のガリ版刷りがある. 
うである. ゙トトロイトへ蔺い, Michigan の大学へゆく. 空からみるアメリカは荒箖としている。一寸都会外一出 ると空地で，落葉樹の森がさびしく枝をのばしている。 デトロイトの飛行場 (Willow Run) は戦封けの工場の 跡だ，その感じがき泏しである。この辺アメリ力の笑 業家はきでしいような気がする。に゙うでもよいこと一一 客の吸引にはこんなところをかざりたてる必狂はあるま い一に焦って金を出さないのであろうか。ここはデト ロイトとAnn Arborとの中閒である.Ann Arborは 大学町である、西部のStanford 大学では自陲東通いの 学生が多いがここは自転軎である。校舍の前にずらりと 並んでいる。この町は美しくデトロイトの金持の住宅地 でもあり，弪罳第二と言うオーデトリアムるありよい 音楽や何かが寔々くるのである. Huron 河心ジルフ場 に㳂って流机ている，大きな落葉樹がにょきにょ立っ ている風景は英国にいるような父がする。ただ男女学生 の風紀が少し違って見えるのであるが，ここで心理関係 では W. H Hays に出会った。心理学に拊ける統計の 応用について考えて居り，特に二つ以上の変量間の関係 (これは現象解析に特に大甽である）についていろいる よく調べていた。これと言って新しいす法を出している わけではないが，体よくまとめて考えている所は目をつ ける心゙き所につけ，実用にさとい，学生为便利なことで あろうが,本質をよく辨えさすこと，そ机によって䛊用を 避けさすことる非常に大切である。この点が心配である。 后薬は口に苦しは洋の其鸣を䦌かない。ここで Grant

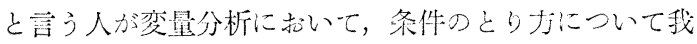
หのような荐え力で接近しようとしていること范堼いた 27). 数学教室に A. H Copeland がいる. 確摔論で は sequence の確率諭の立埸に立ち, von Mises の系 列の選択についての第二条件に制限を加えた restricted randomness に立ち admissible number (一程の systematic sampling）を提是していた人である。また最

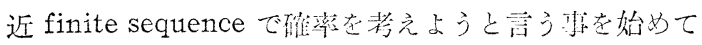
いる28). 管て声った finte sequence (H. Blume, Mathematische Begründung und Entwicklung einer Wahrscheinlichkeitsrechnung) とは異った立場 から行打うとしているものである29). 私には理諭子興味 はあるし，会うことに好大変興睏が放った。いかにもュ

27) Psychological Bulletin, March, 1956.

28) Theory of probability of finite sequence として Berkeley Symposium, 1956 に論文を発表する予定。

29) こ机については近く本誌上で論究する予定でむる。
ダヤ人と言った颜つきの老人であった. Koopamnn に よる intuitive probability（これはある仪設の下で finite sequence に關係がつけられる)30)には強く反対 している、私に同意を求める有㥞であった。これは人々 の行動の予测 (intuitive な安心感, 满足感に立って, 或 は立ち迷ってしかもある有利と言う，汰断に従って行う 行動と言うことに対しては説明原理として興昧あるるの である）と言うことに対する説明原理としては面白く思 えるのであるが，このままでは統計解析においいて一寸用 いて有効でない(或は用い得ない)ように思えるのであ る31)，彼の理諭も proposition のあつまりにおいてブ 一ル代数を用いる.しかし，こうして後予测とか成功率 (successrate) とか-一非常に統媩的なアイディアであ る——重視して理諭をつくりあげるとの或であった。 また彼は我々の数量化について基た興味をるっていた。 科学基礎論学会の打至話してみると，この行き少に大変 な関心を示していて，连絡をとりたいしへっていた。こ この教室にはまた代数たやっている Harrary と萑う人

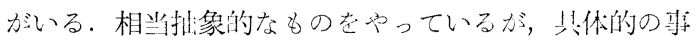
にも強い関心を示し，ここの Center for Group Dynamics の Cartwright (心理学梦攻, 现命は group dyn-

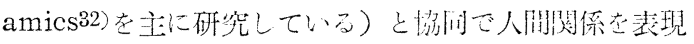
するために graph theory t発展さ边ている。このると となるのは D. König による Theorie derendlichen und un-endlichen Graphen, Leipzig, 1936 である。こ れに目をつけて落えを進めている。これが New York のChelsa Publishing 㕕社で 1950 作に阴㸝されて居 り, group dynamics の柴失などは, 㑔をかかえて勉 学していた。このような協间㫵㠰はいずれにせよ羡まし い限りである. Cartwrightは 50 䋐以上の人である心

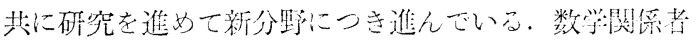
も外に目を古け，他の分野のものもそ礼老理解しとり人 れ，相携えて新しい领域を切り抔こうとする努打はい るのである。一見思いるかけない提势がある. Harrary は，数学者で他の分野に日をむけるものは僅かで，自分 などはそのうちの一人たと苦っていた。この発鹰も近々 のことで内容は機械的で，またそう取り立てて苦う䅌の

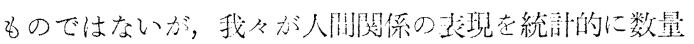
化して（勿諭多次元的にではある沈）いるのとはちがっ

30) B. O. Koopmann. Intuition probability of sequences, Annals of Mathematics, 1941.

31）何とか発展する余地はあると舁らが。

32）小グループの人間開係や交啮に打いて生ずるdynamies を研究声る 
て，克すびつきの関係をそのま〉代数的にみてゆこうと

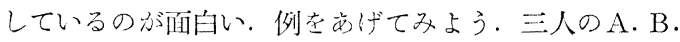
Cと育う人がいるとする。この閩係で
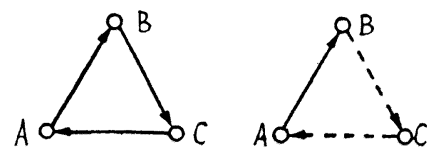

任し $A \rightarrow B$ は $A$ が $B$ を好むことを表し， $A \longrightarrow \longrightarrow \rightarrow$ は $A$ か を㧛うことを表す

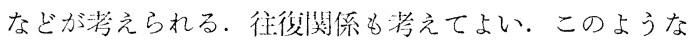
関係をるとにしていろいろ集団と楧造の特性を代数的に 解析してゅこうと落うのである33). 一つの例としてba1ance と言う概念を忍げてみよう.

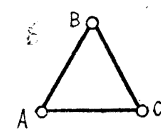

甲́

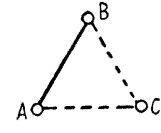

乙

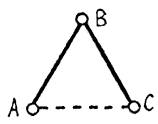

丙

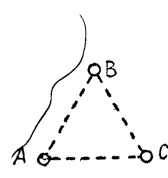

$丁$
简学のため: 人の䦌係が犬々 positive(一), negat-

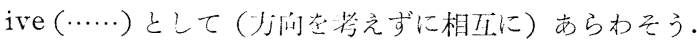

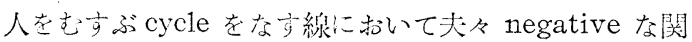
係方偶数である場合を balance と言うのである. 甲， 乙は balance で内，丁はそうではないこの意味は $A$ と $B$ とが仰がよく $B$ と $C$ とが仰がよけれ沿 $A$ と $C$ と

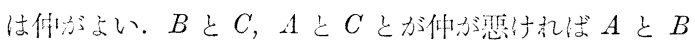
とは仰方よい， $A$ と $B$ とが他がよく $B$ と $C$ とが件が よく $A$ 之 $C$ とは仰が羿筞々。こうみるとbalanceは

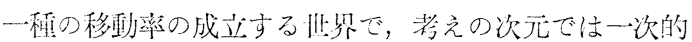

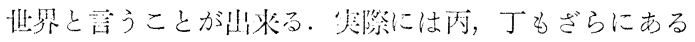

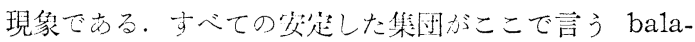
nce と高うのではなくこのような balanced group の特 色をとりあげて，n人のグループに括ける balanced

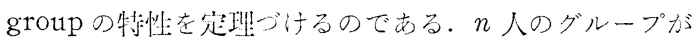
次の二つの其迎缸分をるたない部分（そのうち一力は筀 集合でるよい）—间一のグループ内の者间志の間の関 係はみな positive でことなったグループ同志つ関係 はすべて negative である一ーにわかれるならば，また その时にのみ balance をるつことになる。これは互に

33) Harrary による一速の睮交は Annals of Mathematics, Transactions of the American Mathematical Society, Prcceedings of the American Mathematical Society とかそ の他数学の雑点化発裴されている. また Structural balance: a generalization of Heider's theory (Cartwright 々共沁), psychslogical Bulletin, Vol 63, No5, 1956, は発屋の一つのレヴ イニーである. 䨀本となるおのは Graph theory as a mathematical model in social science, Ann Arbor, (Iastitute for Social Research) にある.
相反目する結合グループにわかれることを意味する34). 例えばこのようにして集団構造の分類や取扱いを考えて ゆくのである、こ机だけではしかたがないので，このよ うに記述された（記述，説明であって子測に使打うと考 えていない点で Cartwright は正しい. $A$ と $B$ とが 仲がよい， $B$ と $C$ とは仲がわるい， $A$ と $C$ とは如何 であろうかなどの予测をこの考えで処理しょうとするこ とは明らかに䛊りであるが，ここの西流はこの種の研究 をやっている) グループと group dynamics の現㑰と 比較してゆくことに興味があるのである.

Michigan の Institute for Social Research には二 つの大きな部分 Center for Group Dynamamics と Survey Research Center とがある.ここも所属は Michigan の大学であるが破究所の運営は殆に゙独自にや らねばならぬので研究費稼ざで大変だそうで，教授級の 人々は飛ずあるいていると言う. 研究員約 50 人, 助手・ 補助員 130 人の職員がいる（200人の調查員をのぞく） と思われるので仰队大変であるう。これをいくつかの project でまかなうのであるから，研究频も随分出する のであろう。出方方では基礎研究への投资 35 上考充てい るのであろう。

ここの Ross \& graph theory であり, matrix 表示 ではなく視覚的に行く行き方をとっている。一间 graph theoryにとりつかれているようである。いつか我国 へもこの流行が波及することであるう36. Cartwright は group dynamics の方の堅である. 考えの面白い人 である.我々の方法一統計的に多次元的に，メトリッ クを考えて集団構造を解明する一在説明し，graph theory との対总をこころみた。ねらいは同じでも接近 の片法全くことなり，夫々特色がある。な初 group dynamicsの研究は事の性質上一一䘽雑な人间の interaction や性格によるのである一小数の実験をしたの では自説の率強附会の一助となるばかりで，追試も何も きいたものではない，ここでは50組位㷂験して，仮設が 説明されなければ失敗として報告するそうである。この 失敗の記録は大切なるのである. 我々には興晰媣い。こ この observation room 文たが Harvardのとは比 较になるぬるので日本なみであるがただ数が多い、観察

34)内容的には二つの世界であって, balance とは震い得ないかすし

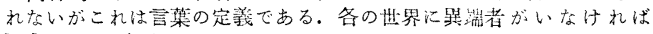
balance の意味になる.

35）これが新しい技術を生及その見返りとして工業界が摔益されると需 う兒方が盛である。

35）このま」ではそう有難いるのには思党ない。これだけでは不毛であ ろら. 
者をも観祭できるような仕組みになっているのはよい著 想で，うまく利用すると自然状態の観察がよく行われる かもしれない。

Survey Research Center には Katona がいる. 経 済予測で，人間の行動を重んじてゆくやり力で，我队の 考え方と进だ近いのである。この事についてはスェーデ ンの所でも触れた37). 考え方は明快であって活父があ る. outside variale のはっきりしたもの（経済予测, 選挙予测）をもとにして研究すれば，これに関係づけて， 理論の妥当性を確かめ得て, 方法論の講究が進展すると 言う。我从の考えているような事を言う，留间と答えの とり方，つかい方は全く操作的で“正確”ではなく“妥 当”を中心に考えるのである．解答はその条件の下にお いて得られた一種の媒介变数，と考えればよいとの立場 である．解答の一間一間はよいがそれではどうしてくみ 合わせてゆくかが問題であるが， cross tabulation の みで成案がない，あれば教えてくれと言う。予测に対す る我々の考えている力法を論議した33)。 いまは消費者 の動向調查を継続しているが，いまこんど新に笑棊家の 調查をはじめ，両者つき合わせて経济予测をやろうとし ている，経済予测はマク口的にはうまくゆかず，いろい ろなパーソナリティの人々のさまざまな環境の下での行

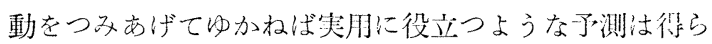
れない，景気の変換点の予䨐とか，きめの組かさとかに 於て，笑業家の面接は難しかろうと訊权てみたがこのさ かさまで非常に容易であるそうである、部者会見で即れ ているせいであるうか39).この本についての望胃があっ たら述心よと言い consumer survey をよこしたが， 自信慢々である，仲々よい。よんでみると各垩因項目と outside criterion (消費動问)とを関係づけているとこ ろで，各琹因が独立と見倣せるから，各要因则に論ずれ ば—こうすれば多次元的解析にならず極めて容易であ る—十分であるとあるのでこれが间题の篎所である。 やってみると，一寸赫顔をして，それは籍の走りで， この projectをもらっている以上，何とか絬羭をつけ

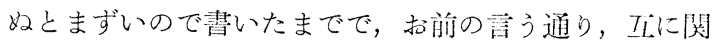
連がある，この次に出すときはよく検討して綜合的に分 析するから見ていてくれ，との寺であった。いずこも同 じ弊があるようである。注意しなければならないのは

37）そこにあげた交献参照.

38）本誌第 2,3 号「現像解析に括ける統計的方法」参照.

39）アメリカの実業家も商い税金にくるしめられている.しかし調圭を 税金とすぐむすびつけないようである，日本の場合はこの關题がむづ かしい.
読者である。このような占を则にして Katona の仩什

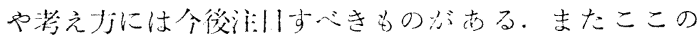
Campbe11 は盗等》河题で Group differences in attitude and votes 忺して，测心を少しているのだ面

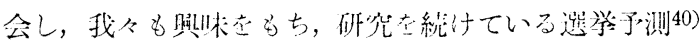
について論じてみたいと焽ったが多忙で留方であるのは 残念であった。

こ机に比してつまらないのは sampling の分野であ る. L. Kish がいているいる似师在しているようである

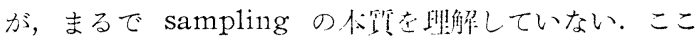

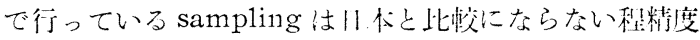
が恐い，佃人の samplingでは non-response は15\%程

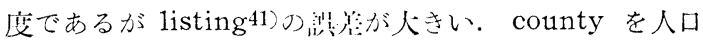

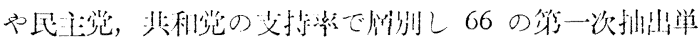
位として county を抽惊る。ニッーヨークの入るよう

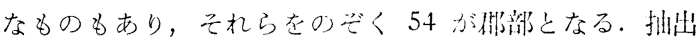

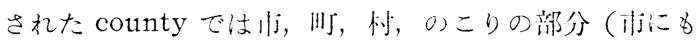
町にも村にも属さない激分，こ机は道路等で区切る）な

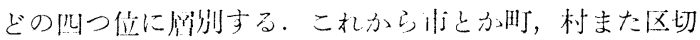

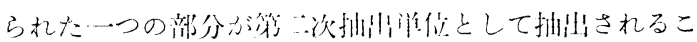

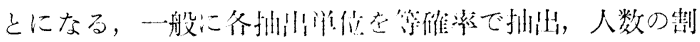

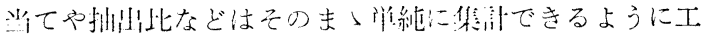

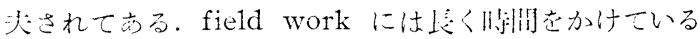

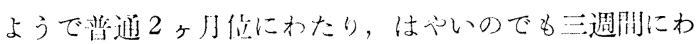

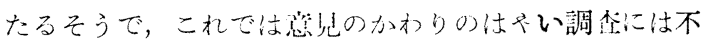
適である。

ミシガンの大兴には时恻多いが半ズボンの女子学

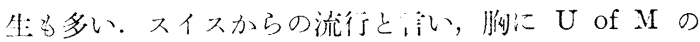
マークがついている。大学焩であるだけにワシントンと 其に物俱はきわめて们いし，领佔们ではHarvard とか Yale とか何とか大学の多のーいた料理が先ら机ている。 のんでりとした町で go-stop \&きたんとして理涂通りで ある。

ミシガンからシカゴは一飛づである。飛行機の棜周表

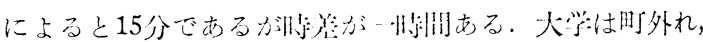
Midway の我行埸加らまっすぐの所に市る。直舆的な 感じのする建物で，前には少生の公团がひりけ，Michigan 湖が high way42)ごしにながめられる。この辺り は关しい，芝生の川の情物鸰问ひ池やその池に下りる階 段のきわまで水怔さていのもよい. Michigan の湖岸

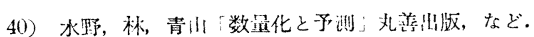

41）アメリカでは名淮を川いない，むる区州を油出すればそこに在住す ろ人々のリストをつくり，これからサムプルを排仙する。

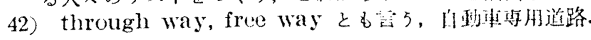


からみると向うは工籍地带が雪み一方には高屏建築が立 ちならび，アメリカらしい，川の流れるように自動車が 超スピード（牌速60〜90㕷位）で走る.9 条の線がひか れ，往復 8 本の道に走る.自㽖才の制込みなどは殆どな い. high way での十字路は殆どすべて立体父叉である. こうしなけ机ば交通量はさばけないＵ-turn は絶刘に 許されない，立体交叉であるので左か右か人まがるのも 道筋がちがう。よく標識をみて自分の行く才问をスピー ド霆転し午ら判断し，しかるべき道を走ら权ばならない。 自動車はとめられないし速力救るあられない，後がつ かえているのである.間違ったとしてもU-turnできな いので，すぐとってかえすかけにはゆかない，大备りし て厓時間をつかってまたもとの所へ出なければならない 全く速に判断を下す能力が不可火である。この交通をな がめて, high way traffic の統忛の意味がわかる。こ の手法を high way の殆どない日本の普通道路へうつ せば笑いものである，日本の显通つ交通では解析の仕方 が異るのである。なるへく多くの交通量をさばこうとす るかをみるために，統润をつかうのであれば目のつけ所

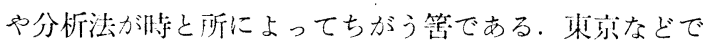
はロンドンなどと间じく道がせまいので go-stop の時間 間隔やいかに一力交通路をつくるか，それを据間的にど う変えるかなどが䦌题になる䈂である43). high way で

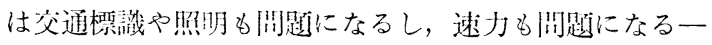
一いかにして安全遇転させるかが间题.

Chicago の大学の統针姀空は Eckhart Hall にある.

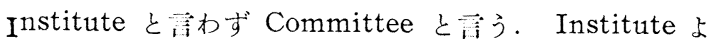
り小さいのである. 数兴教公は Instituteである.ここ には Leo A Goodman と Savage がいる. Mathematical Statistics の部会が開かれるので皆多忙であった。 Savageには会う护は出来なかった. Goodman とは前 から連絡があり，伩积放の㝋测なぼで我々の研究に興味 をるっていた，彼は社会器の教授でもあり，興味の対象

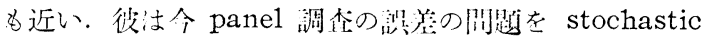
に取圾って扂り，然験るやっていると苚っていた。これ は面白い間题である. Goodmanには他に目集四の大き さを推定しようとするよい研究多ある44). また Biophy-

43）ロンドンは道もせまく，東宗よりるかに交通最がより多く目動車は とまったきりなかなか動かない、ニーヨークは道路が広いので何と かなるがやはり東京式である。

44） $\mathrm{N}$ 人のものがあり, その各は $k i$ 個の同じ梌識をもっている. $\underset{i=1}{N} k i$ $=K, K$ 调のものから何䈍かの方法で samplingして，その中に何人 新しい人がいるかをみる。これを $\mathrm{n}$ とする、n から $N$ を推定する 關速などあとりあげている。 sics の Rashevsky ひいる. 会うなり自分の苦状をな がながとのへ出した。「大学の評議員は怪しからん，研 究の事はわからず，勝手に人員を整理したり，研究費を けずったりする，大学の制度は日本と独逸がよい」と言 いだした、日本子前はよかったが何故か戦後アメリカの 真似に夢中になる人がいて，評議員会のようなものをつ くり出し，わけのわからない無资任な人たちが抽象的な 勝手なことを言い，これが「公正」として通るのだから 困ったものである，一こ礼をまじめに人におしつけた 学者さえいるのであるから一ーとのべざるを得なかった. 人のものがよく見えるのである.16人いた研究員が 1 時 に3〜4 人にされたと言うのである.また日本のある人 の書いた数理生物学の本の $\frac{2}{3}$ は自分の本の全くの剽窃だ と言って喷慨し，その人に会いたいといきまいている. 弱り目に崇り目である. Rashevsky は実験には全く興 味なく，いままである現象を一つの仮設のようなるのか ら数学的に構成することにのみ中心があるようである. 笑験と対応づけるのは拓前達統計家の仕事と言う.これ には全く恐れ入って了った。任意な仮設で，あてはまる かどうかかからない体系一言葉だけは極めて現象的な ので何か豪づけがあるのかと欺されて了う一一を作り出 しても自己满足しかないかもしれない，これでは研究費 が削減されるのは無理もないかもしれない. 考え方とし ては面白いところもあるので一歩ふみ出せばよさそうで あるが, Rashevsky にはもう無理であろう.

Chicago の大学には原子力研究のはじめと言うお城 のような, 牢獄のような建物が有名である. Chicago の 市外に原子力研究の講習会があり，ここへ每年日本から 4〜5 人の研究者が研究にきているのである.

Chicago からロスアンゼルスへは無著陸でゅく. Grand Canion も雲の下にある. 長い飛行なので，操縦 室を見せてくれるようにたのむとO．K と言う．エンヂ ンの調子もブラウン管に出るし，メーターの綜合も自動 操粉式が多くて，これをよむ気安さは10 年前とは隔世 の感があるが，しかし堅忍不拔つ精神だけは鋭敏さと共 に今でも必装のようである。

アリゾナ，コロラドの曠野，灌溉の水がほそく茶色の 芫地の中を通っている。そのまわりや四みのみえる内側 には線がみえる，水をまつ土地什田虫のように囲みだけ 見える.ロスアンゼルスに近づくと急に緑が映える。だ だっ広く拡がった都市である，砂漠の上に灌溉で出来上 った都市なのである. 水も遠くから引いてくる45). アメ リカの開発土木事業も今に始まった事でなく，歴史があ 
り，その経験に培かわれた理論と技術がある.ロスアン ゼルスは背の高い建築は少く, 平家が多く, 自動車の使 利によって横にひろがった都市である。ここには天父予 報に加えて smog の予報と言うのがある. 重油を多くつ かうのでこのガスがたまってロスアンゼルスの上空 1500 〜2000米にたなびくのである.これがひどくなると人々 の目もいたくなるほどである。これが $\operatorname{smog}$ である、発 生するとサイレンがなり，工場が重油をつかう扑を禁じ られ，自動車も特別のものをのぞき運転してはならなく なる，不便なものである， smog がうすくても，空はか

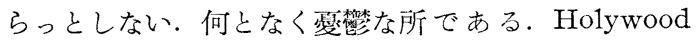
へゆく電車はきれいであるが 30 分に 1 回と言うので誰

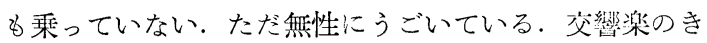
めの荒さ, 力強さも，2万人入ると言う野外劇場の Holywood Bow1 をみては首肯される。攵れなりに，その美 しい自然を背負った背景をみれば納得のゆくものである。 Beverly Hil1 はここの美しい住宅地で，通りによって 植えてある街路樹も異って，なかなかよい，庭の手入れ は日本人が上手と言うので，在留邦人のよい代乩なっ て1ヶ月 600 ドル位の収入があるそうである. Santa Monica の海岸も名ほどの重はなくつまらない海岸であ る、日本の海の美しさをしみじみ思う．海岸のよしず张 りの代りにコンクリートでかためた駐車場がある。一劃 は自炊できるようにドラム罐やコンクリートの非戸杵の ようなるのが扔いてあり，中へ重油がきていると言う。 石油の檞はいたる所に立ちならび海岸にのり出していた りゴルフ場の中にも立っていたり，する46)。このそばに 墓場と競馬場があるのもとりあわせが面白い.こう言う 自動車万能の所では后にしろ劇場にしろ，まず自動本爂 場をつくらねばならず，これが全く広い面稓をとってし まうのである、西海岸へくると気候のせいかけばけばし い色彩が目についてくる、いかにも植民地の感じがする. ここのホテルにも勾論聖㫷がある。他に読み物がある ので何かとみるとホテル王 Hilton の出生物語り（処非 訓) 'A practical guide to successful living' や小 エッセイ集とがある。自分の社長の出低物語りを置いて いるのはいい父なるのであるが，これが通用するのには 何やら小供らしい健全さがみられる。

45）少し前大雨が降ったところ排水が考えてなかったので全く飛んだ事 になったそうである.急な城の多い, いつもは雨の少いサンフランシ スコでも雨が澺のように流れて大事になったよらである.この種の事 故も日本にばかりではない. 何年計画にも限度がある.

46) 石油が出ると地主は油田の樵一本につき一日に 50 ドル位入るそ5 である。
アメリカの家庭人はそんな意味で健全のようで，目曜 には何でも教会へぞろぞろ行き，家族と一悢に遊ぶ。一 寸した美しい土地や池があると cottage を览てボート

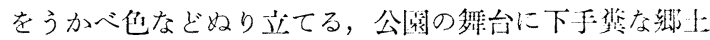
舞踊があると一家てろってあきずにながめて楽しんでい る.オクラホマと言う活動が何っ月もあきずに上演さ机 ている・アメリカ人のたのしみはささやかなるのである

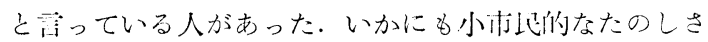
である。このごろははやく家庭をもち子供が多くなって いる傊问である，于供づれをみても3 人〜 4 人が多い. デパートには姬斻服のファッションが尘にかざりたてて

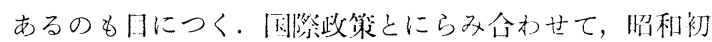

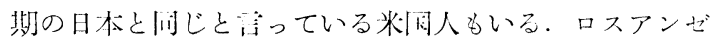
ルスを正てアメリカ生活の昧父なさをみせつけら机た感 じである。全くコクのない断罚のようである。

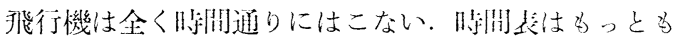
速く，うまく行ったときのものであるから必引゙待たされ ると方ってよい、しかしこれは植にはならない、たえず 去来する飛行機の形き仙どり，ての所㢄の同々が私をた のしませてくれる．潜で船の恬入をながめているのにも 似ている。ここにはひたひたと打つ波や瑟色の水もない，

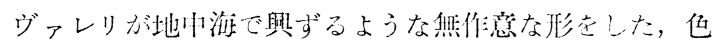

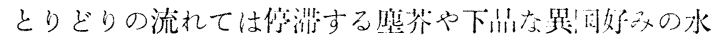

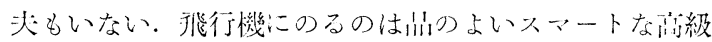

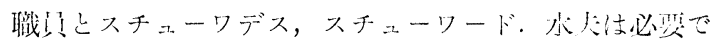

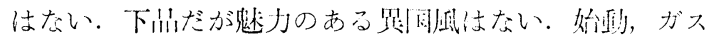

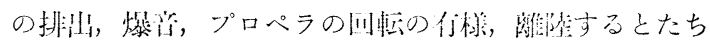
まち形のかわる资，仙とりどりの DC-6B，DC-7，スト ラトクルーザー，コンステレイション…. Air France の飛行機がつくと一寸毛出沙ってスマートである. SASも括ちついている。デザインは火切なものだ。 っきりした無に緑の芒生，コンクリートの滑造路，そこ

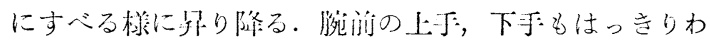
かる. 悲の exotic にくらべで゙っと丁軽であるぶ，近

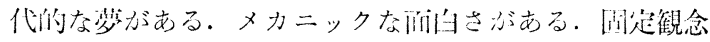
を洗いながす生々とした排渲作汌（警㨫）と大ピードの

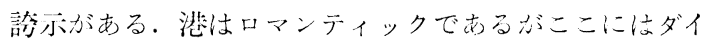
ナミックな快さがある。一睬に少价を沈すようなJet 機 の離陸もある、港や船についてばわりでなく，飛行機や 飛行赫，これらについでのダイナミックな萝を描いた詩 や雄浑な詩もあってよいと恐う. Jet plane と题して E11sworth Taylor と䒫う人が赫をつくっているのをみ たがあまりうまいものではない47). 
カリフォルニヤの大学はサンフランシスコから Bay Bridge をわたった Berkeley にある.「率の狳佰にかけて

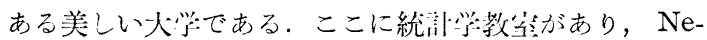
yman ボこれをひきいている。

Neyman とは animal population (mobile population）の話をした。㷛の population の䦌题をポアソン

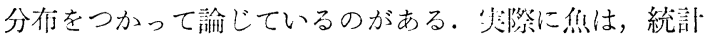
のとりあつかうように磼率的に独立なるのとしてあつか ってよいかどうか当てにはならないように思える，個从 别々の间題で倠かめて行か朴ばならないであるう。百に 独立でない壦合の捍アソン分有についてバクテリアをの ぞいて出した研究溯文は而档いものである48). Leslie 達 のやり片は反対であった。 equal probable の入れ力 や群生の间题に刘してである。ある地域に生楼の㣍の総 数の推公の話をすると自分の論文をもとにし考えれば何 とかなるうと苚っていた。我々もこの破究をいろいるな

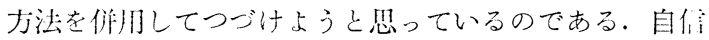

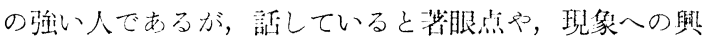

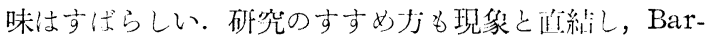
tlett と界に学芯べ人であると思う。

Le Cam のマルコフプロセス, Hodge の演滉一大

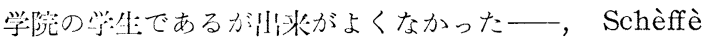

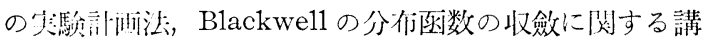
義（これらは大学脖のもの）をきいてみた。やり才は日

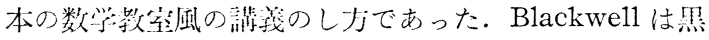
人である，匴義に岕ているものが 2 人であり，他にくら ベ间题にならず少かった。照人の分離间题でされいでい る折，僻目をもちたくなるような们䪞であった。

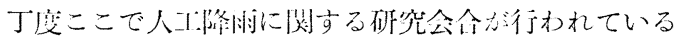
所であったＮNeyman が chairman である、統汁家と

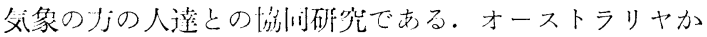

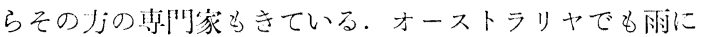
くるしみ，カリフネルニヤも湖で㸵しんでいる。なんと

47) ((Overhead, something is sudden. High silence dies) (Hard, slashed to flat shrieks by spaceflinging) (Sabers of sound. This whistler down the skies) (Swoops the horizons like a garden swing) (Slung from the stratosphere, man or beam flown, (Fueled with distance, Jeweled full of flash) (To levin up a fortress or a town) (And rain it gently on the landscape ash.)

(Each instrument, instant to serve the the flame,) (Frees the devine robot of the pilot soul) (From this hard work of flying, but for one aim,) (Which, held by safe screen watching ground control,) (Along converging beams of brutal will) (Sanctions the guiding brain to make it kill.) 括张は行の変り目をあらわす。

48) Annals of Mathematical Statistics, 1939359 頁以下また J. B. Douglass, Fitting the Neyman type a contageous distribution, Biometrics, 140-173 頁, 1955.
かして雨をふらせたいのである．小さな水塊をまく仕方 がとられている。この效果があったかどうかを統計的に しらべようと言うのである。この水塊をまく方法が問題 なのであるが，なかなか統計家の思うようにならず，デ 一タの分析もあいまいになって了う, Neyman は randomized block でまくべきだろうと私を顧みて言う， しかし現䒠はこうやってはいない，実際に研究はオース トラリヤの方がさかんである.カルフォルニヤの役所で はそこまで鄪用を出さないそうである. randomized block でも水塊をまいたとき，連鎖効果が出て次第にま かない所へも雨か降らないたろうかと質間してみたらそ んなことはないだろうと言う， block の長さが200〜300 嘿もあると言う。これには警いた。生駒山で沃化銀を空 へあげている日本とは此較にならない。

Neyman はまた面白い問題にとりくんでいるわけで ある。しかしデータがうまくない（雨の観测地点のとり 方もいままでの測候所だけであるか

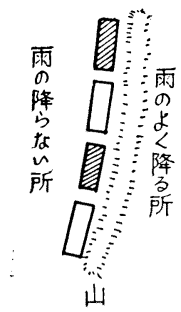

禀まく所

】まかなり所 ら大したことはない）せいか，研究 会は低調で，統計家の分析 (Scott 女史）なっていないし，気象家の 統計のとり方は全くいい気なるので ある一一自分に都合のよい説明づけ だけである——、まだまだこれから の閌題であろう49). Stanford 大学 はサンフランシスコから約 1 時間半, Palo-A1to にある．構内の植物は熱 带的な感じがする。平らな石造りの 建物で一寸イスラェル的である. 棈 内は恐るしく広く, 池や牧場子大きい.町から大学入行く には自動車がなくては全くかなはない，私の行こうとす るのはこの構内にある Center for Advanced Study in the Behavioral Sciences である.これは Ford Foundation で出来て居り笑陵に仕良も始めたのは 1954 年 の秋からであり，所只は50人である。任期は一年である.

49) 当日の演题は

R. R. Reynolds, Weather modification operations in Calif. E. G. Bowen, Snow mountains cloud seeding project (オー ストラリヤ)

E. L. Scott, Effect of storm types on the relation between rainfall in target and in comparison areas.

A K. Brownlee, Statistical aspects of the problems of cloud seeding experiments.

特別講演として

E. G. Bowen, Formation on natural and artificially induced rain,

な扰これについて

Weather modification operations in California, Publication of State Water Resources Board, Bulletin No 16 がある. 
優秀な behavioral science の研究者—これはせまい 意味のもの, 心理, 社会, 人類学のみではなく, 人間に ついての ‘成熟した科学”を発展さそうとする中心問題 に関係のある他の分野も含むもので，idea や才法論も 言うに及代ず法律, 政治学, 経済, 商学, 歷史, 哲学, 数学, 生物学その他の humanistic studies を含んで いる——をあめて, 本職から解放して自由に研究させ ようと言うのである。こうして人をあつめ自由に接触さ せて新しいものをつくりあげさそうと言う楽園である50)。 いかにも現代的で派手な生徒達を離れて, 爽やかな池ご しにみられるゴルフ場に隣る丘の上にあるのがこの $\mathrm{Ce}$ nter である.しかしこの丘も人口的に緑化したのであろ う.灌激用の噴水が回転している. 右手は芝生の大きな 起状で类に広い，美しい木が点々とある。ここは超モダ ンな日本趣味をとり入れた建築（倉の建築の木組の模 倣）の平家木造である. 黒く彷ってある.リゾートのホ テルと菩った感じである. 大きなガラス張りのロビーと 図書館が正面から見えるが，色とりどりで，スダレが shade につかってある. どうみてもセパレーツの水着 を着た女達が出入りするに相応しい。もっとも彼女等は カヌーのゆれる下の池のボートハウスのテラスや砂浜で 海水着のままねそべって戯れているのだが，部屋は蛸足 式にいろいろな才问に出ていて，ての中もホテルのよう な感じである.今日は Guttman がいないので Eisenstadt にあう. 彼は Hebrew 大学の人でイェルサレム で会う約束をしていた人である．社会学者で年代別の社 会学的考察，イスラェルの移民の問題，イスラエル社会 学などを講究している人である. 年代別では日本の特殊 的なもの, 男では保守, 進歩の入机かわりが 35 40才の 間であり，女では25〜30才の間でかわることなどに非常

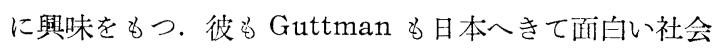
を調查したいと言う。日本での調查は甘く考えると見当 外れになる，非常に複雑なことを警告しておいた。アメ リカで最近発行になった Kibutz（キブッ）と言う本を みてよくない本であると言っていた。 イスラエルに居住 しユダヤ人社会の尃門家としての彼はそれに不满なのは 無理もない、な扢ここの砳究所にはユダヤ人が随分多い ように見うけた。

この研究所をみて，我々にはここでは落ち著いて研究 できそうもないような感じもするし，なにか軽薄に流れ

50) ここに Excerpts concerning the Center for Advanced Study in the Behavioral Sciences, (202) Junipero Serra Boulvard, Stanford Calif.) なる案内パンフレットがある.
はしまいかとの感じもした。しかしょく洘えてみると深 刻さはなにもうすぎたない喑い部屋からのみ生れるとは 固定観念のようでもある. 叮るい萧やかさの環境もあっ てよいようである. 深陵そのものもうちかえしてみる必 要があるのかもしれない、額に㖪よせた賚愁とあかるい dynamic なセンスとの対比. なにか一寸我々が既成の 観念のため盲点になっている所を将えさせられるようで あった。なにもこれがよいと言うのではなく，もう一度 観念の結合の自由性をとりもどしてみることを刺战され て面白く感じたのである.

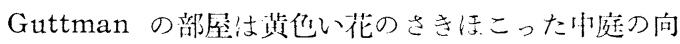
うにある. 一つ隣りは心理学某の L. Festinger である. 体格や顔つきれがっちりしているが白っぽく采和である。

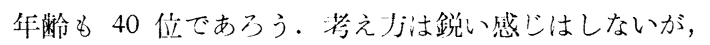

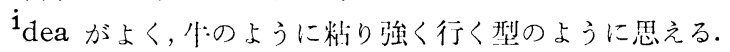
訢仙いろいろつきない.まず一見 consitency のないよ うな（移動率の成立しない上うな）現俰の多次元的な取 扱いの訢汃入った。拉に formulate しなおして議 論する. classification の多次元的な取扱いの間题的論 ずる51). Guttman \& generalized variance や linear

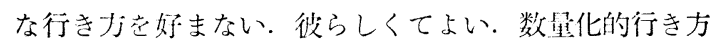
は拉互の立場である。今やはり facet design の理論52) に熱中している. paired comparison は判断者のくい ちがいが入るのでやに難しいと高う， factor analysis

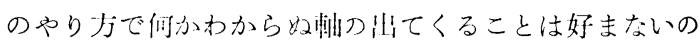
である.しかしこの少面に斧を入れた L. L. Thurstone

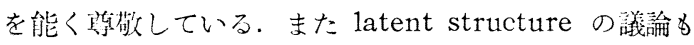
factor analysis と分の scale theory の間にあると して,やはりそう阔倜してはいない.しふし彼とても scalable の现象つ少い現尤に, 目分つ理淪つみで押せる とも思っていない. scalableをもととしての principal component としての理渝沬行くところまで行かした感 じで他へ転じて理䜽をひらこうとこころみている53).そ

51) University of Michigan で行つた Conferencs on imultidmensional analysis, 1954 は面白い。この中には Guitman の Generalized theory of structure があるがこの他面白いものもあ

52) 本鞋第 8,9 当参照

補足すると facet theory では, facet の啭念は要因の概念である.

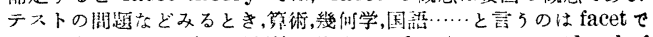

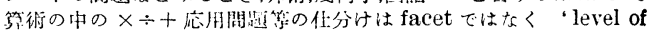
complexity'として通す行き方をとると棓っていた. facet design とはことなるが,この levelを明かにして行く一各 level は独立と みる—のに別に radex 㺺論を券えている。このやり方の一部には 直交系をつくるSchmidt法の䓅えに近いものが体われている. Doob の stochastic process一章をむ示してみせた. radex 理論は factor

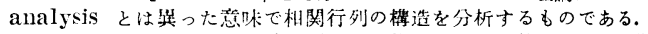

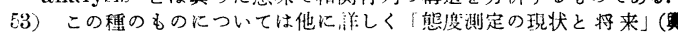

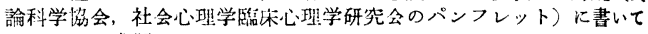
扣いたので参照されたい。 
こで仮説をたててものをみてゆこうとする facet theory を考えているのである. また factor analysis を このごろよく取扱っているのであるが，あたえられた調 查事项の scaling は何でやるか，それは相閉係数の出 せるような数值となっているか，これを無祝したのでは 後退しているように思えると吉ったところ，いま sca1-

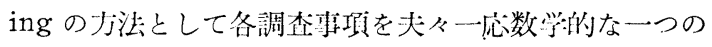
次元にとり (而交軸), 各調查杰项の閉係がすへて linear な関係をもち，招互の多次元的な関係が而朴関関係的意 味で鼠大の相阅をつように scale をしなおしてから factar analysis を行うと问っている54).これはたしか に面白い才法である.しかしこれから出てくる factor は 従来のような解瀵をゆるすものではない. 多次元的表现 をより少い次元へ迟化せし女る一つの操作として学える ハきざある。この要当州は outside variable への尒测 として検䚯せられるべきであろう。そうであれば，

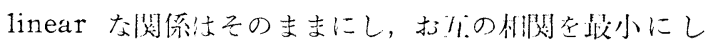
てゆこうとする行きうる浸えてよいのである。またもっ

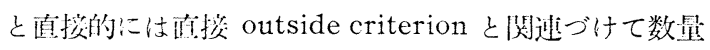

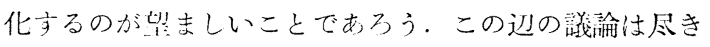
ないのであるが，いず机にしても factor analysis の根

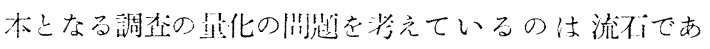

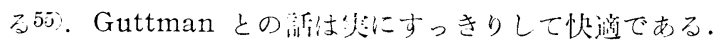
勘所をついて而白いのである。机成係数を川いての予测

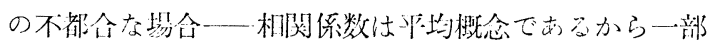
分よく于测き机，他が全くだな埸合など綃合してこ机 によって四报うの法不理である——゙うやっていくか， をつっこタイ个ったが做か了测つうまく行くような分類が

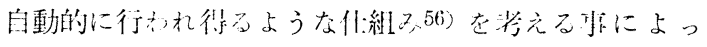
て可能で作に formulation してみようとけう据にな た.

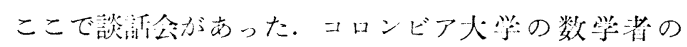

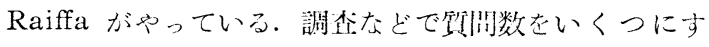
るのがよいか，をやっている. sequential decision の

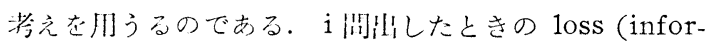
mation のたりないこと)，それからつぎに间を出し調杰 军ことによって拉こる infornation の墔加とそれに

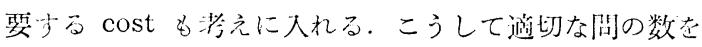
きめてゆこうとするのである。これに頞間をしているも

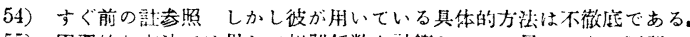

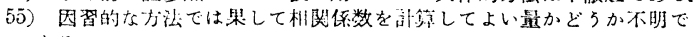
ある。

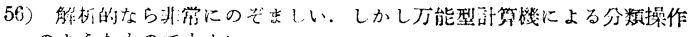
のよラ京ものでもよい。
のがあるがどうも sequential の本質を解しないし，社 会調查の方法論もあやしいようなもので情なく思ったが， Marshak と Hurwitz (共に経済学者) である.ちがっ た分野のことであると非常に根本的なことをきいて理解 し，そこから自分なりに，その問題一の示唆を与え，ま たそれにより自分が稗益されるのかるしれない.つまら ないことで知らないことをたずねる勇気はよいが，時間 がかかる，論議は活潑である．しかし Raiffa の根本欠 点は質問のならべうである. ここが大切な点である.こ の順序が䑤視されてあるのか現実的ではないＧuttman と共にまあまあと言う所で議論はしなかった。

Raiffa の話し力は実によく，意味を十分明説して，式 の演算はなく，結果を書いてみせるだけである．話をす すめるアイディアについてはよく話す．ここで異る各分 野共通の地盤できて各々立場から，考えをもちよれるの かもしれない.これでいろいろの分野の研究協力が可能 となるのであろう. 知らないこともこうした雲囲気の中 で覚えてゆくのかもしれない.そうすると技術的な事は さて执き，根本の考え力はつかめそうである.これが一 番大切なことと思う．とにかくこの談話会はいろいろな 意味で非常に面白い見物であった。

ここの研究所はたしかに研究速絡と保善にはよい.い ままで仕事がたまってつかれたとき，ここで本職を離れ て処理し，お互に考えを交換し研究連絡をする，そうし て新なアイディアをみつける，こうした事に適している. しかしながく住みつく所ではないようである。すすみつけ 代研究も温窒的な理諭きどうでもよい抽象的な遊戯にな る危険があると思われる，社会に生活して，現実的必然 的問題とぶつかって，立派なるの（広義）がうまれてく るのであろうと考えられた。

ここの食堂のグループ棈成は面白い，ユダヤ人同志は 分野をはな机て、よくかたまっているようでもある.

D. F. Aberle と共にインディアン調查の design をGuttman と共に颜し合ったが，罗の子が生れて Stevenson と名づけたと言って二人に葉卷きをくれた. 四の子が生れると友人におくるのだそうである，Festingerに会ってみようとしたが Guttman はそんな必要は ないと言う。この二人も前からの論敵なのである.

サンフランシスコの町に時間と温度と同時に表示され るランプの広告がある、たえずついたり消えたりしてい る. 温度がそんなに大切なのかと不思議である. 銀行の 貯金の広告である. Berkeley にある Guttman の家は 山の上にあり一眙の下にサンフランシスコを見渡せる. 
ここので食事はイエルサレムのと全く同じものであった にはおどろいた. Center でも Guttman は金曜ははや くかえらねばならぬと慌てていた。家族はイスラエルの 話をすると大嬉びであるが，Guttman はあまり好きで ないらしい，夜の香のたちこめた中を彼と共に山の中腹 にある Claremont のホテル (tremendous hotel と彼 は言う）へゆく．外侧は古典的であるが内側は例によっ て日本障子の design がとり入れてある.この.1ounge で一杯飲もう，と言う内部は全くうすぐらい.大きな 1ounge のガラス戸を通して両名は飽かず灯の海をなが めている.くっきりした淡碧の空に星がかがやき，目の下 には檳榔樹がしげる，atom の現象をみるように小さい

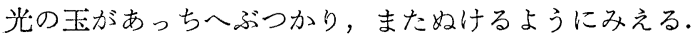

自動車のライトである. Bay Bridge も近く星をつらね, Golden Gate Bridge b遠くかかって星を小さく連ねて いる. 飛行機のライトもちらついている. lounge の向 うではピアノ引きの女をとりかこんで男たちが回りで低 い声で合唱している。これがとぎれとぎれにきこえる. 酒杯のさざめきがきこえる，西洋だなあと旅の終りで感 じ出す、すへて終った気安さからであろう．いまは彼も 自由にイスラエルを語る。アメリカの略語にイスラエル 的のものも多いにはおどろくと言ったら嬉んでいた。 BWY,BLVd PRBLM, INTRSTNG……間に母音が ない57). 日本は面白い所だから是非行きたいと言う.

ここを最後にサンフランシスコを立った. ものすごく 急な坂にケーブルが走り，湾中にある囚人島を港から遠 眼鏡でのぞいて遊ぶ人達もあり，Fisherman's Wharf でゆで蟹の露店や魚介料理屋のならぶサンフランシスコ はもう日本に近いような気がする58).

ハワイは日本人の意気揚々たる所である. ロスアンゼ ルスの在留邦人の打ちひしがれたみじめさとは打ってか わった明るさである. 第二次戦中の二世からなる第 100 部隊, 442部隊の活躍で日本人の status はぐんと上って 発言権を增したのだそうである. 摘売もよいし, 要職に めついている，移民の一つのゆき方である，ハワイには 面白い開発がある. 海岸のリーフをこわし，媣く堀り， 砂をもってきて砂浜をつくる．こうして泳ぎ得る海岸を つくろうとしていることである。世に有名なワイキキの 浜も実にせまいるのである。あまり邆浅すぎて満足にお よげない.しかしこのため波があとからあとからきて波

57) Broadway, Boulvard, problem, interesting

58）西海崖の大都市ロスフンゼルスとサンフランシスコは全く性格のち が5都市である.一方は古いにほいのある老舖の町であるが一方は全 く新しいアメリカの町なのである。

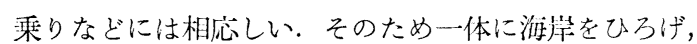
泳げるようにし，ホテルを建て，劇場をたて，ますます 観光客を吸収しょうと芦うのである．そのホテルの建築 をみても日本調がとり入れてある。ここの開発は何か一 寸味気ない気もする。アメリカも大きいが泳げる所は少 ししかない. マイアミ，ロスアンゼルス，八ワイ，有名 なのはこの位であとは芜海か寒流のため寒すぎておょげ ないと言う。ハワイはマイアミを打ち負かそうと言うの である。

我が国の統部研究の現状をみるとやはり，研究者が尠 いと言うことになる．話しあっているうちこれこれの専 門家は誰かと聞かれると大抵の場合言葉に笘して了う。 実に多いと思っているが少いのである．少いと言うより 文献渉猟・整理家が多く皆同じようにつっこんでいない 一般論ばかりをしているのである. 現象にとりくんで， 我々に必然的なものを追求して長い間研究を積み新しい ものをつくりあげてゆこうとしている人が抄いのである. この分野の研究が新しく始められたもので全く伝統のな いためであるかもしれない. 修行の途は遠いような気が する。

これで書き止めようと思うのであるが，最後にいろい ろな点で統計の国際比較の危隃性をかかげておこう．各 国には各国の生活様式と物価とがある。翻訳の言葉は同 じでも内容の全く異ることもある.アメリカの都市で自 動車の無い事は生活をおびやかするので，或るところで は電気冷荿庫のないことも生活しきれい事を意味する。 一週間の買物をして，泠藏咸にしまい込んでそれで食事 をつくりあげてゆくのである，自動本をもつことは贅沢 ではなく，生活の基本ともなるものである，そのように 社会がつくりあげられて了つているのである. またアハ リカでは鉴車の事を考えると自動本は不便なもので，む しろ地下鉄の方がよいこともある. 自動車の一人当りの 台数や，使用電力量で文化程度がはかれるものではない のである．比較は別の観点からしなければならない，こ の点はややもすると犯しやすい．為替レートで国民所得 などを比較することも沿秩である，例えば 1 ドル 360 円 で計算して生活程度をくらべこともおかしい.アメリ カにはアメリカ的生活があり，保険への出費なども多い。 これがないととんでもない损罥瞕償をさせられると言う。 また食費に至っては1ドル100 円とみなけ机つすあい がとれない，交通費も同様である，日労生活に必要なる 
のの此較は 1 ドル360円では全く飛んでもない部算にな るのである59). これにくらべて我々にとっての贅沢品の 方は安い、白動直は闍題にならず, テレビ, ラヂオ……な ビ全く安いのである.1ドル1000円でもよい位である60). 単純な国際比較は全く䛊解させるもので，むしろやる ベさではない，深く突闸んで内容を極め，そこから鿊え なおさね代ならない、此較には全く異った scaleがつく

59）一空の生活（2 人家族）は少くとも 1 ケ月 300 ドル以上は必要であ ろ5.ドル月給の換算に 360 円を掛けて安心するのは飛んですないこ とである.

60） 日本の説店とのちがひは，日本には一般にそ5高価なるのは尠く， 旋ったものもないが, アメリカやイギリスの一寸した店では非常に上 等の做性あるものむ売られている. 価格の高いもののが多いのは日本 とのちがいであろう.
られ，その上にのせてみなければなるまい。これる一つ の研究課題かもしれない.

ぞこの国も不思議な国である，不思議でない国はなか った、単純に割り切ることの危さをますます感ずるに至 った.

西洋にも佝僂の国へ行ったなら

みんな佝僂にならにゃあならぬ

せめて佝僂の真似せにゃあならぬ

と言う俗謡があるそうである.

\section{科学基礎論学会昭和 31 年度総会と講演会報告}

昭和 31 年 11 月 3 日東京大学に於て第 4 回総会が開催され，続いて講演会に移り，以下の如き研㭝発表が行われ た.

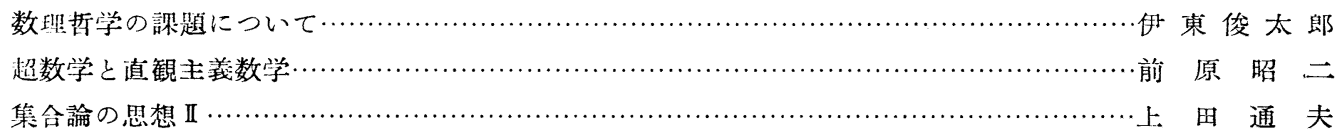

12 時より 理!事会

13 時より 講演

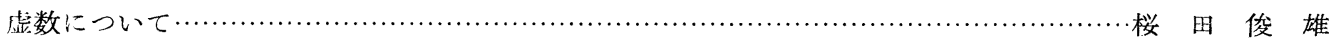

フレシニの確率行夘構成について

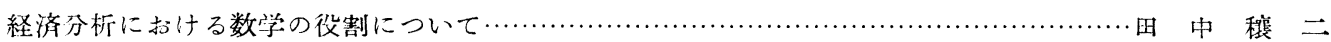

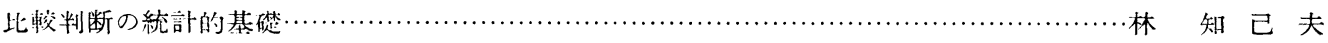

社会性のトポロジー的定義とそれに基づく研究方法の開拓について……..............阿部孫四郎

15 時 30 分より 特別講淀

唯物諭と科学.

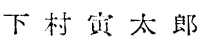

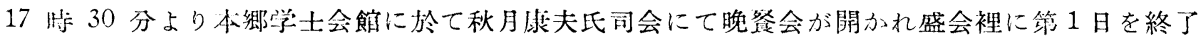

11 月 4 日前日に引き続き 10 時より講渞会を続行

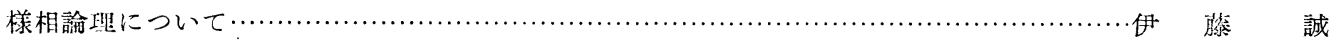

排中律の成立しないある論琶系について

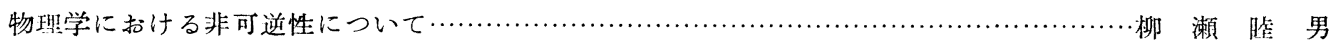

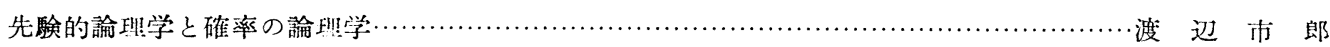

14 時より

「科学基礎論学会のあり方について」と題して傠論会に入った要旨下記の通り

科学基礎論学会のあり方について

講演（第 2 日）についでこの題目の下に，座談会を東大理学部会議室に招いて開いた，参会者は高木委員長，未綱， 下村，山内，大江，雬永氏等をはじめほぼ㴖員の盛況であった。先ずこの座談会の提唱者たる故を以て秋月が司会す ることとなり冒頭に次の挨拖を行った。「今回の講演会は予想以上に盛会で即論も活潑であったのは慶賀に堪えない. 